\title{
Current Distribution and Status of Amphibians and Reptiles In Will County, Illinois
}

\author{
David Mauger \\ Forest Preserve District of Will County (Retired) \\ 17029 Henry St., Lansing, Illinois 60438
}

\section{Thomas G. Anton}

Field Museum of Natural History

Roosevelt Road at Lakeshore Drive, Chicago, Illinois, 60605

Illinois Natural History Survey Bulletin

Volume 40, Article 1

February 2015 
Prairie Research Institute

Brian D. Anderson, Interim Executive Director

615 E. Peabody Drive, MC-650

Champaign, IL 61820

Phone: 217-333-5111

Fax: 217-265-4678

prairie@illinois.edu

Illinois Natural History Survey

Geoff Levin, Acting Director

1816 South Oak Street, MC-652

Champaign, IL 61820

217-333-6880

cms@inhs.illinois.edu

Citation:

Mauger, D., and T.G. Anton. 2015. Current distribution and status of amphibians and reptiles in Will County, Illinois. Illinois Natural History Survey. Bulletin 40(1):1-32.

For permissions: contact the Prairie Research Institute.

Editor: Charles Warwick

US ISSN 0073-4918

US ISBN 1-882932-36-6

$\mathrm{P} 1090131-.45 \mathrm{M}-02 / 2015$

(C) 2015 University of Illinois Board of Trustees. All rights reserved.

Printed with soy ink on recycled and recyclable paper.

The University of Illinois will not engage in discrimination or harassment against any person because of race, color, religion, national origin, ancestry, age, marital status, disability, sexual orientation including gender identity, unfavorable discharge from the military or status as a protected veteran and will comply with all federal and state nondiscrimination, equal opportunity and affirmative action laws, orders, and regulations. This nondiscrimination policy applies to admissions, employment, access to and treatment in University programs and activities.

University complaint and grievance procedures provide employees and students with the means for the resolution of complaints that allege a violation of this Statement. Inquiries or complaints may be addressed to the Director and Assistant Chancellor, Office of Equal Opportunity and Access, 601 East John Street, Swanlund Administration Building, (217) 333-0885, fax (217) 244-9136, TTY (217) 244-9850 or the Associate Provost and Director, Academic Human Resources, Henry Administration Building, (217) 333-6747, fax (217) 244-5584. For other University of Illinois information, contact University Directory Assistance at 333-1000. 


\title{
Current Distribution and Status of Amphibians and Reptiles In Will County, Illinois
}

\author{
David Mauger \\ Forest Preserve District of Will County (Retired) \\ 17029 Henry St., Lansing, Illinois 60438
}

\section{Thomas G. Anton}

Field Museum of Natural History

Roosevelt Road at Lakeshore Drive, Chicago, Illinois, 60605 


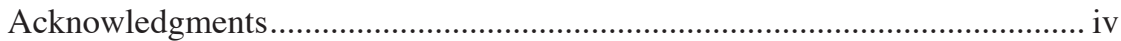

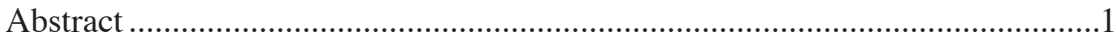

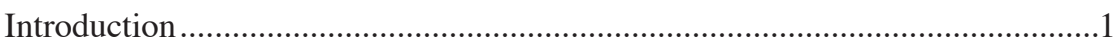

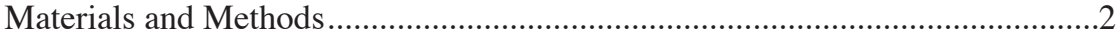

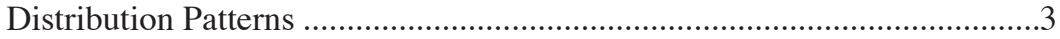

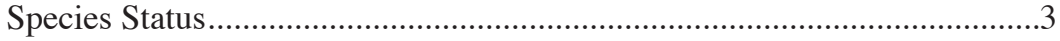

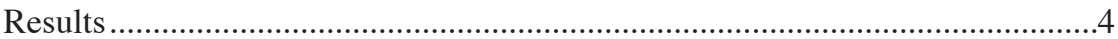

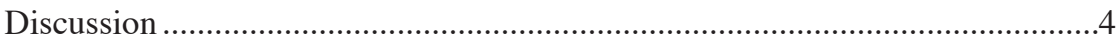

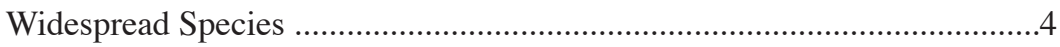

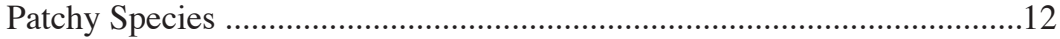

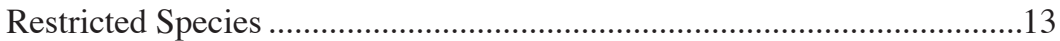

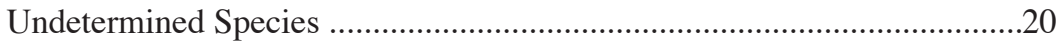

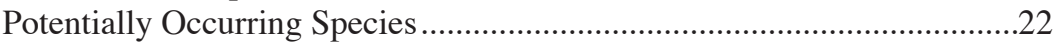

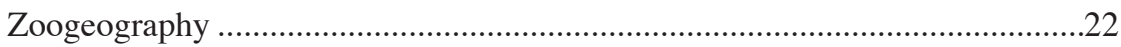

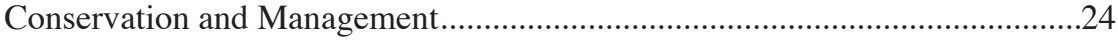

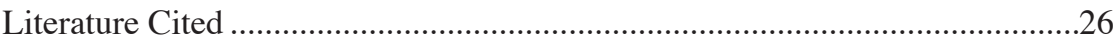

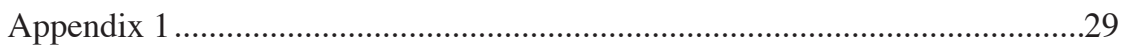

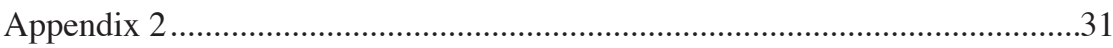




\section{ACKNOWLEDGMENTS}

We thank Juanita Armstrong-Ullberg: Forest Preserve District of Will County (FPDWC), Whitney Banning: Illinois Natural History Survey (INHS), Dave Beamer, Glen Buckner, and Cori Crawford (FPDWC), Mike Dreslik (INHS), Rebecca Key: United States Forest Service (USFS), Andrew Kuhns (INHS), Rob Miller: Illinois Department of Natural Resources (IDNR), Mike Redmer: Unitd States Fish and Wildlife Service (USFWS), Alan Resetar: Field Museum of Natural History (FMNH), Dave Robson (FPDWC), Bob Rung (IDNR), and three anonymous reviewers. Special thanks to Kenneth Mierzwa whose initial involvement in the beginning years was the impetus to make documenting the distribution of Will County amphibian and reptile species a career-long, if not lifetime ambition. 


\begin{abstract}
The distribution of amphibians and reptiles in Will County, Illinois, was assessed using museum records and results from 58 surveys conducted between 1986 and 2009 on lands owned and managed by the Forest Preserve District of Will County (FPDWC) and Illinois Department of Natural Resources (IDNR). One hundred and twenty sources of information were examined including technical reports, theses, dissertations, and personal data belonging to the authors. Forty-eight species (19 amphibians, 29 reptiles) were documented by photos or specimens from Will County. Eleven species were determined widespread and common, 6 were categorized as patchy distributions and are uncommon or locally common, and 23 were found to have restricted distributions and are considered rare, including seven state-listed species. One of those state-listed species (Sistrurus catenatus) is likely extirpated. Eight species had undetermined distributions, four of them of questionable occurrence. One of the questionable species (Anaxyrus fowleri) is no longer included in the current list of Will County herpetofauna because it has been determined to have been an introduction and no known population exists. For three others (Terrapene carolina, Pantherophis spiloides, Nerodia rhombifer) we were unable to conclusively interpret their records and they are assigned questionable status until further records confirm existence of viable, selfsustaining populations. Of seven state-listed species (four threatened, three endangered), one may be extirpated (Sistrurus catenatus). Lithobates sylvaticus, Hemidactylium scutatum, Ambystoma texanum, and Eurycea cirrigera are glacial relicts that are highly vulnerable to extirpation due to pollution, isolation, and a warming climate. Presently, 43 species (18 amphibians, 25 reptiles) are known to occur in Will County, making it the most species-rich county in the Chicago region.
\end{abstract}

\section{INTRODUCTION}

Will County is the 13th largest county in Illinois $\left(543,043\right.$ acres/848.5 $\mathrm{mi}^{2} ; 219,762$ hectares $\left./ 2,197.6 \mathrm{~km}^{2}\right)$. It features $9 \%$ urbanized land, $46 \%$ cropland (1.2\% of state), $7 \%$ woodland (1.0\% of state), $30.4 \%$ urban and rural grassland (2.4\% of state), $2.7 \%$ open water (lakes, rivers, streams, $1.9 \%$ of state), and $3.1 \%$ wetland (1.4\% of state; Illinois Department of Natural Resources 1996). Significant natural community types include prairie, savanna, sand prairie and oak-dominated sand savanna, wet upland forest (flatwoods), wet hardwood forest, wet bottomland hardwood forest, and floodplain forest. Little undisturbed prairie remains in Will County.

Much of Will County's wetland, prairie, and woodland habitats have been altered through draining, agriculture, timber harvesting and other development practices. Fire suppression allowed many non-native, predominately European, plant species to encroach on native ecosystems. Consequently, old field and degraded shrub land are dominant habitat fea- tures. Pesticides may have reduced the numbers of some sensitive species, particularly insectivores such as smooth green snakes, Opheodrys vernalis (Harding 1997). All habitat types have been reduced in size, fragmented, and isolated. These phenomena are detrimental to generally immobile and localized populations of amphibians and reptiles.

The Forest Preserve District of Will County (FPDWC) was founded in 1927 and manages 21,000 acres $(8,498$ ha.) of land for wildlife refuge and human recreation. Will County is represented in the older literature about the Chicago area herpetofauna in the form of short monographs and published species lists (Garman 1892; Schmidt and Necker 1935; Necker 1938, 1939; Pope 1947; Edgren and Stille 1948; Stille and Edgren 1948; Smith 1961; Pentecost and Vogt 1976). These lists are documented by extensive collections of preserved specimens deposited in the Chicago Academy of Sciences (CA), Field Museum of Natural History (FMNH), Illinois Natural History Survey (INHS), and some out-of-state institutions. 
Since work conducted by Smith (1961) and Pentecost and Vogt (1976), herpetological inventories and research projects have been conducted throughout the Chicago region (Ludwig et al. 1992; Anton 1999). Extensive data were accumulated on Will County herpetofauna, much of them in the form of unpublished reports to the FPDWC. Initial work photodocumenting records started in 1985, followed by preliminary surveys by the senior author for salamanders in eastern Will County (1986) and spotted turtles in central Will County (1987).

The foundation for a comprehensive account of the county's herpetofauna was initiated a year later by Mierzwa (1988), but current published literature is scant (Anton et al. 1998; Brown and Morris 1990; Bavetz 1994; Mierzwa 1998; Redmer 1998). The purpose of this publication is to summarize all unpublished studies, published literature, museum collections, and other information accumulated on the distribution of reptiles and amphibians in Will County.

\section{MATERIALS AND METHODS}

Museum specimens and associated locality data from the following institutions were examined: Academy of Natural Sciences-Philadelphia (ANSP), Chicago Academy of Sciences (CA), Carnegie Museum (CM), Field Museum of Natural History (FMNH), Illinois Natural History Survey (INHS), Louisiana State University Museum of Zoology (LSUMZ), Milwaukee Public Museum (MPM), Museum of Comparative Zoology-Harvard (MCZ), Northwestern University (NU-located and managed at the Chicago Academy of Sciences), Southern Illinois University at Carbondale (SIUC), Tulane University (TU), University of Illinois Museum of Natural History (UIMNH), University of Michigan Museum of Zoology (UMMZ), and the United States National Museum (USNM). We also included unvouchered records (records without specimen vouchers) based on photographs or reliable observations in the INHS database, and our field notes, photo records, or unpublished reports of the authors.

We reviewed data from 120 resources, including 73 technical reports, 4 masters the- ses, 1 doctoral dissertation, 10 peer-reviewed publications, 11 conference presentations and posters, and our personal data files $(\mathrm{n}=22 \mathrm{DM}$, $\mathrm{n}=18$ TGA). Much of the above were products resulting from 14 general herpetofaunal inventories and 44 single-species research projects conducted on lands owned and managed by the FPDWC or on other state or federal land from 1986 through 2009. The single species surveys often provided additional specimen or photo records, and incidental observations of other reptiles and amphibians. Surveys used standard methods (Heyer et al. 1994; McDiarmid et al. 2012). More recent records from 2009 to 2012 were added to our database for species that represent either new county records or historically occurring species with scant records. Observations of species from a 2013 survey at three sand area preserves in southwest Will County and a 2014 survey at another preserve in western Will County near Channahon are included in the discussion, but were not added to our database.

We salvaged any dead animals found on roads (DOR) or in the field that were in good condition. Specimens were preserved in $10 \%$ formalin or $95 \%$ ethanol (if designated for tissue/DNA sampling), stored in $70 \%$ ethanol, and deposited at the FMNH and INHS herpetology collections. All specimens from Will County in CA, FMNH, INHS, NU, and UIMNH collections were examined by us or verified by the institution's collection staff. Localities from institution catalogs, database printouts, and specimen tags were visited if possible to verify existence of suitable habitat and the continued presence of uncommon, rare, and/or state-listed species. Only general reference to localities, without maps, is discussed to protect sensitive locations. These data are available through the INHS.

We compiled a spreadsheet of all records and used ArcGIS (ESRI ArcMap Version 9.3) to plot records and assess species distribution with respect to three major physiographic sections: the Northeastern Morainal (NM; 277.83 $\mathrm{mi}^{2} / 719.5 \mathrm{~km}^{2}$ ), Grand Prairie (GP; 494.64 $\mathrm{mi}^{2} / 1,281 \mathrm{~km}^{2}$ ) and Kankakee Sands (KS; $76.76 \mathrm{mi}^{2} / 198.8 \mathrm{~km}^{2}$ ) following Schwegman (1973). 
We used proximity analysis in Arc Toolbox to plot a $1.0-\mathrm{mi}(1.6-\mathrm{km})$ diameter buffer around each record to represent a $0.8-\mathrm{mi}^{2}\left(2.0-\mathrm{km}^{2}\right)$ locality area per each record. Records with overlapping areas were dissolved to create a single polygon of larger areas considered single localities that were summed to yield total locality area for each species. We correlated total number of localities and total locality area for each species and visually inspected the graph to find breakpoints useable for operational definitions, categorizing distribution patterns into four categories: widespread, patchy, restricted, and undetermined. We believed our locality approach would be a less biased measure of species occurrence compared to plotting individual records, as some species had numerous records from a single site.

We assigned current status for all species into one of five categories: common, locally common, uncommon, rare, and questionable. Status is evaluated from a landscape-scale perspective at the county level. Definitions for categorizing distribution pattern and species status are given below.

\section{Distribution Patterns}

Widespread (W) species typically had 20 or more localities and displayed obvious and well-distributed occurrence patterns spanning all three physiographic sections. These species were numerous and frequently encountered at most if not all preserves surveyed. They were also encountered along roads or other areas near or in between FPDWC survey sites. Exceptions to the locality number criteria were made if our experience indicated the species was more widespread than the current number of records indicated.

Patchy $(\mathrm{P})$ species had fewer localities $(>5$ and $\leq 15)$ and were usually countywide in distribution (or occurred in at least two physiographic sections), but occurrences were widely scattered with large gaps between localities and infrequently encountered over the years.

Restricted (R) species had 16 or fewer localities and the occurrences were highly clustered in one or two geographic areas of the county. Species known from single to several localities were considered "Restricted" when we were confident there was sufficient survey effort in those areas to exclude false absences nearby or elsewhere in the county. Several of these species are restricted to specific physiographic sections or portions thereof and are rare, have state threatened or endangered status, are glacial relicts, and have specialized ecological, habitat, or microhabitat requirements.

Undetermined (U) species had five or fewer localities that did not meet operational criteria for designation as "Restricted." These species were either of questionable occurrence or were underrepresented in past collecting events and in recent surveys.

\section{Species Status}

Common (C) status was assigned if the species showed a widespread distribution pattern and many localities (usually $\geq 20$ ), and where they were encountered frequently at localities on and off FPDWC property.

Locally Common (LC) status was assigned to some species with a patchy distribution pattern and comparatively few localities (> 5 and $\leq 15$ ), but our experience indicates they are readily encountered, and multiple individuals were observed at most localities. It also applies to turtles where we predict their distribution pattern would show clustering around major river systems if riparian surveys were conducted.

Uncommon (U) species had patchy distribution patterns and were infrequently encountered, usually as single individuals, at most localities. Some species afforded this status may be common at specific sites, but extant populations based on recent (post-1985) records are few.

Rare (R) status was assigned to species showing significantly clustered distribution patterns, usually in a single geographic area or physiographic section, and in a few instances to two areas or sections. Rare was assigned when we had high confidence that our sampling effort was sufficient to avoid false ab- 
sences. The number of localities varies widely from single to (rarely) $>15$ localities (usually < $7)$. In a few cases, some species were found in moderate to high numbers at some localities but restricted to microhabitats that are extremely restricted or rare countywide.

Questionable $(\mathrm{Q})$ status is assigned to species recently documented by one or two records, or those that had no historic (pre1985 ) records to support their occurrence in Will County. The nearest records occur at great enough distances that mechanisms for natural dispersal or range extension are unlikely in a fragmented landscape. This status also applies if the record is not supported by additional observations, photos, or specimens indicating the presence of a viable, self-sustaining population. Species in this category may represent escapes or releases of captive individuals.

\section{RESULTS}

A total of 1,511 records (1,106 vouchered, 69 INHS unvouchered, 336 author unvouchered) of 48 species, represented by 19 amphibians (11 frogs, 8 salamanders) and 29 reptiles (2 lizards, 10 turtles, 17 snakes) are documented for Will County (Fig 1; Tables 1,2). Thirty species of reptiles and amphibians were documented prior to 1985, with both the Kankakee Sands and Northeastern Morainal sections poorly surveyed for turtles, and the Northeastern Morainal Section with few records for frogs (Table 1). Forty-eight species have been documented in recent times with no significant difference in total species richness across the three physiographic sections (Table 1). The Grand Prairie Section had the lowest species diversity in salamanders (2) and only the Kankakee Sands Section had the two lizard species (Table 1). Four townships in eastern Will County had the greatest number of records ( $n=636,42.1 \%$ of total records), followed by eight western townships $(n=381,25.2 \%)$ and four southwestern townships ( $\mathrm{n}=366$ records, $24.2 \%$ ). Central Will County ( 7 townships) had the fewest records $(\mathrm{n}=128,8.5 \%)$.

Of the 48 species documented to occur in Will County, 11 (22.9\%) were widespread, 6
(12.5\%) patchy, $23(47.93 \%)$ restricted, and 8 $(16.7 \%)$ undetermined in distribution pattern (Table 3).

The 11 widespread species included 5 frog, 1 turtle, and 5 snake species. An example of a widespread distribution pattern is shown for the common garter snake (Thamnophis sirtalis; Fig. 2). The six patchy species included one salamander, two frog, one turtle, and two snakes species (Table 3 ). An example of patchy distribution pattern is shown for the milk snake (Fig. 3).

The 23 restricted species included 7 salamander, 3 frog, 3 turtle, 2 lizard, and 8 snake species (Table 3 ). Seven of the restricted species are state-listed, including Hemidactlyium scutatum (IL-Threatened), Necturus maculosus (IL-Threatened), Clemmys guttata (IL-Endangered), Emydoidea blandingii (IL-Endangered), Terrapene ornata (IL-Threatened), Clonophis kirtlandii, (IL-Threatened), and Sistrurus catenatus (IL-Endangered). Eight species had undetermined distribution patterns including one frog, five turtle, and two snake species (Table 3). Historically, 30 species were found in Will County (Table 4).

\section{DISCUSSION}

\section{Widespread Species}

Of the 11 widespread species, the total number of records for L. clamitans was one less than our category criteria of 20 localities, but our experience indicates it occurs in far more localities than currently documented. Further, the paucity of records for all widespread species in south-central Will County is attributable to a lack of available habitat in what is predominately agricultural land. Some clustering and gaps between records exist for species such as $C$. picta, N. sipedon, L. catesbeianus, and L. clamitans that favor large rivers, streams, marshes, ponds, and reservoirs. All 11 widespread species were found to be similarly widespread and common in other Chicago region counties (Anton 1999; Brodman, et al. 2005) and were assigned common status.

Continued on page 12 


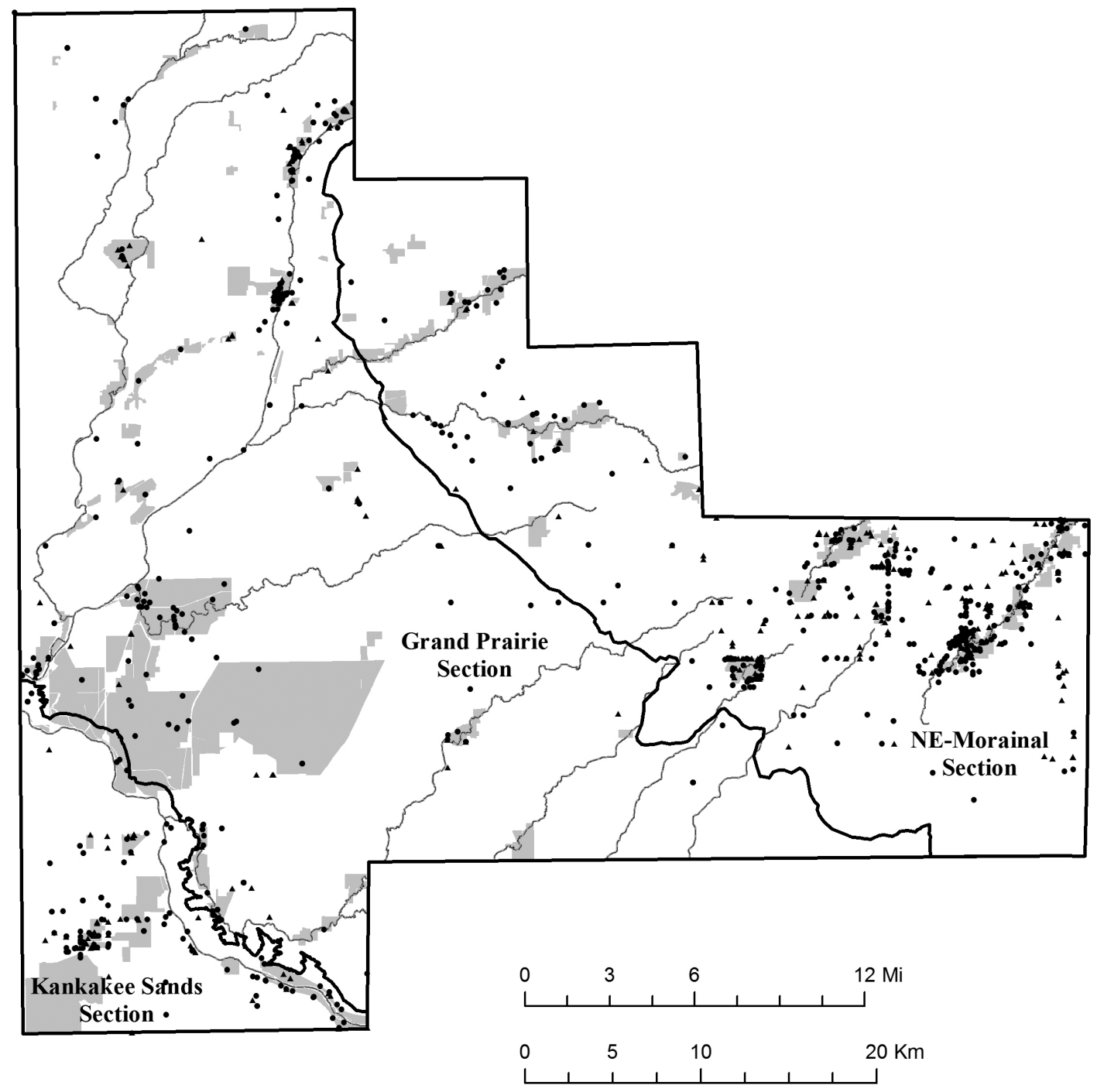

- Vouchered Record

- Unvouchered Record

Preserves

- Physiographic Section Boundary

Major Rivers \& Streams

Figure 1. Total records of amphibians and reptiles in Will County. Note: INHS records in our database are inclusive through 2010 and the senior author added 336 personal unvouchered records in 2011. There are several INHS records from 2011 and 2012 included also, but our database is not inclusive of all INHS database records for 2011-2014. 
Table 1. Checklist of Will County species.

\section{Species}

\section{Anura}

Acris crepitans

Anaxyrus americanus

Anaxyrus fowleri

Hyla versicolor

Pseudacris crucifer

Pseudacris triseriata

Lithobates blairi

Lithobates catesbeianus

Lithobates clamitans

Lithobates pipiens

Lithobates sylvaticus

\section{Caudata}

Ambystoma laterale Ambystoma maculatum Ambystoma texanum Ambystoma tigrinum Eurycea cirrigera

Hemidactylium scutatum

Necturus maculosus

Notophthalmus viridescens

\section{Testudines}

Apalone spinifera

Chelydra serpentina

Chrysemys picta

Clemmys guttata

Emydoidea blandingii

Graptemys geographica

Sternotherus odoratus

Terrapene carolina

Terrapene ornata

Trachemys scripta

\section{Squamata, Sauria}

Aspidoscelis sexlineatus

Ophisaurus attenuatus

\section{Squamata, Serpentes}

Clonophis kirtlandii

Coluber constrictor

Pantherophis spiloides

Pantherophis vulpinus

Heterodon platirhinos

Lampropeltis triangulum

Nerodia rhombifer

Nerodia sipedon

Opheodrys vernalis

Pituophis catenifer

Regina septemvittata

Sistrurus catenatus

Storeria dekayi

Storeria occipitomaculata

Thamnophis proximus

Thamnophis radix

Thamnophis sirtalis

\section{Total Species}

Cricket frog

American toad

Fowler's toad

Eastern gray tree frog

Spring peeper

Western chorus frog

Plains leopard frog

Bullfrog

Green frog

Northern leopard frog

Wood frog

Blue-spotted salamander

Spotted salamander

Small-mouthed salamander

Tiger salamander $\quad$ X $\quad$ X

Southern two-lined salamander

Four-toed salamander

Mudpuppy

Eastern newt

Eastern spiny softshell turtle

Common snapping turtle

Painted turtle

X

Spotted turtle

Blanding's turtle

Common map turtle

Common musk turtle

Eastern box turtle

Ornate box turtle

Red-eared slider

Six-lined Racerunner

Slender glass lizard

Kirtland's snake

Eastern racer

Gray rat snake

Western fox snake

Eastern hognose snake

Eastern milk snake

Diamondback water snake

Northern water snake

Smooth green snake

Bullsnake

Queen snake

Massasauga

Brown snake

Red-bellied snake

Western ribbon snake

Plains garter snake

Common garter snake

\begin{tabular}{cc} 
GP & KS \\
\hline & \\
X & X \\
X & X \\
& X \\
& \\
X & X \\
& X \\
& X \\
X & X \\
X & X \\
&
\end{tabular}

Recent

\begin{tabular}{ll|lll} 
KS & NM & GP & KS & NM \\
\hline
\end{tabular}

X

$\mathrm{X} \quad \mathrm{X}$

X $\quad X$

X

$\mathrm{X}$

$\mathrm{X} \quad \mathrm{X} \quad \mathrm{X}$

$x$

$\mathrm{X}$

$\begin{array}{lll}X & X & X \\ X & X & X\end{array}$

X

$\mathrm{X} \quad \mathrm{X}$

$\mathrm{X}$

$\mathrm{X}$

X

X

$\mathrm{X}$

$\mathrm{X}$

$\mathrm{X}$

$\mathrm{X}$

$\mathrm{X}$

X

X

$\mathrm{X}$

$\mathrm{X}$

X

X $\quad \mathrm{X} \quad \mathrm{X}$

X

$\mathrm{x}$

$\mathrm{x}$

x

$\mathrm{X}$

$x$

$\mathrm{X}$ 
Table 2. Total records, localities, and locality area for all Will County species.

\begin{tabular}{lll} 
Species & Common Name $\quad$ No. of Records & $\begin{array}{c}\text { No. of } \\
\text { Localities }\end{array}$ \\
\hline
\end{tabular}

Anura
Acris crepitans
Anaxyrus americanus
Anaxyrus fowleri
Hyla versicolor
Pseudacris crucifer
Pseudacris triseriata
Lithobates blairi
Lithobates catesbeianus
Lithobates clamitans
Lithobates pipiens
Lithobates sylvaticus

Caudata
Ambystoma laterale
Ambystoma maculatum
Ambystoma texanum
Ambystoma tigrinum
Eurycea cirrigera
Hemidactylium scutatum
Necturus maculosus
Notophthalmus viridescens
Testudines
Apalone spinifera
Chelydra serpenina
Chrysemys picta
Clemmys guttata
Emydoidea blandingii
Graptemys geographica
Sternotherus odoratus
Terrapene carolina
Terrapene ornata
Trachemys scripta

Cricket frog

American toad

Fowler's toad

Eastern gray tree frog

Spring peeper

Western chorus frog

Plains leopard frog

Bullfrog

Green frog

Northern leopard frog

Wood frog

Blue-spotted salamander

Spotted salamander

Small-mouthed salamander

Tiger salamander

Southern two-lined salamander

Four-toed salamander

Mudpuppy

Eastern newt

89

81

1

60

60

36
93

10

29

40

89

2

15
40
1
16
7
25
6
20
19
43
1

$15.1 / 39.1$

$39.4 / 102.0$

$0.4 / 1.6$

$16.1 / 41.7$

$14.8 / 38.4$

$23.7 / 61.4$

$4.7 / 12.2$

$19.8 / 53.8$

$17.2 / 44.5$

$39.5 / 102.2$

$0.8 / 2.0$

$9.8 / 25.5$

$5.7 / 14.7$

$0.8 / 2.0$

$13.2 / 34.2$

4.4/11.6

$1.0 / 2.5$

$1.6 / 4.1$

$2.2 / 5.7$

Eastern spiny softshell turtle

$5.0 / 12.9$

Common snapping turtle

Painted turtle

Spotted turtle

Blanding's turtle

Common map turtle

Common musk turtle

Eastern box turtle

Ornate box turtle

Red-eared slider

$4.7 / 12.1$

$11.0 / 28.5$

$4.7 / 12.2$

$4.1 / 10.6$

$4.1 / 10.7$

$2.7 / 7.1$

$2.4 / 6.1$

Six-lined Racerunner

$1.9 / 4.8$

Slender glass lizard

Aspidoscelis sexlineatus

Ophisaurus attenuatus

\section{Squamata - Serpentes \\ Clonophis kirtlandii \\ Coluber constrictor \\ Pantherophis vulpinus \\ Pantherophis spiloides \\ Heterodon platirhinos \\ Lampropeltis triangulum \\ Nerodia rhombifer \\ Nerodia sipedon \\ Opheodrys vernalis \\ Pituophis catenifer \\ Regina septemvittata \\ Sistrurus catenatus \\ Storeria dekayi \\ Storeria occipitomaculata \\ Thamnophis proximus \\ Thamnophis radix \\ Thamnophis sirtalis}

Kirtland's snake
Eastern racer
Western fox snake
Gray rat snake
Eastern hognose snake
Eastern milk snake
Diamondbacked watersnake
Northern water snake
Smooth green snake
Bullsnake
Queen snake
Massasauga
Brown snake
Red-bellied snake
Western ribbon snake
Plains garter snake
Common garter snake

Kirtland's snake 
Table 3. Summary of county status and distribution pattern for all Will County species.

$\begin{array}{llll}\text { Species Common Name County Status } & \text { Comibstributern }\end{array}$

\section{Anura}

Acris crepitans

Anaxyrus americanus

Anaxyrus fowleri

Hyla versicolor

Pseudacris crucifer

Pseudacris triseriata

Lithobates blairi

Lithobates catesbeianus

Lithobates clamitans

Lithobates pipiens

Lithobates sylvaticus

\section{Caudata}

Ambystoma laterale

Ambystoma maculatum

Ambystoma texanum

Ambystoma tigrinum

Eurycea cirrigera

Hemidactylium scutatum ST

Necturus maculosus ST

Notophthalmus viridescens

\section{Testudines}

Apalone spinifera

Chelydra serpentina

Chrysemys picta

Clemmys guttata SE

Emydoidea blandingii SE

Graptemys geographica

Sternotherus odoratus

Terrapene carolina

Terrapene ornata ST

Trachemys scripta

\section{Squamata - Sauria}

Aspidoscelis sexlineatus

Ophisaurus attenuatus

\section{Squamata - Serpentes}

Clonophis kirtlandii ST

Coluber constrictor

Pantherophis vulpinus

Pantherophis spiloides

Heterodon platirhinos

Lampropeltis triangulum

Nerodia rhombifer

Nerodia sipedon

Opheodrys vernalis

Pituophis catenifer

Regina septemvittata

Sistrurus catenatus SE*

Storeria dekayi

Storeria occipitomaculata

Thamnophis proximus

Thamnophis radix

Thamnophis sirtalis
Cricket frog

American toad

Fowler's toad

Eastern gray tree frog

Spring peeper

Western chorus frog

Plains leopard frog

Bullfrog

Green frog

Northern leopard frog

Wood frog

Blue-spotted salamander

Spotted salamander

Small-mouthed salamander

Tiger salamander

Southern two-lined salamander

Four-toed salamander

Mudpuppy

Eastern newt

Eastern spiny softshell turtle

Common snapping turtle

Painted turtle

Spotted turtle

Blanding's turtle

Common map turtle

Common musk turtle

Eastern box turtle

Ornate box turtle

Red-eared slider

Six-lined Racerunner

Slender glass lizard

Kirtland's snake

Eastern racer

Western fox snake

Gray rat snake

Eastern hognose snake

Eastern milk snake

Diamondbacked watersnake

Northern water snake

Smooth green snake

Bullsnake

Queen snake

Massasauga

Brown snake

Red-bellied snake

Western ribbon snake

Plains garter snake

Common garter snake
Uncommon

Common

Questionable

Rare

Rare

Common

Uncommon

Common

Common

Common

Rare

Rare
Rare
Rare
Locally Common
Rare
Rare
Rare
Rare

Locally Common

Locally Common

Common

Rare

Rare

Locally Common

Uncommon

Questionable

Rare

Locally Common

Rare

Rare

Rare
Rare
Common
Questionable
Rare
Uncommon
Questionable
Common
Rare
Rare
ocally Common
Rare
Common
Rare
Rare
Common
Common

Restricted

Restricted

Widespread

Undetermined

Restricted

Patchy

Undetermined

Widespread

Restricted

Restricted

Patchy

Restricted

Widespread

Restricted

Restricted

Widespread

Widespread

$\mathrm{ST}=$ State Threatened

$\mathrm{SE}=$ State Endangered

*=possibly extirpated 


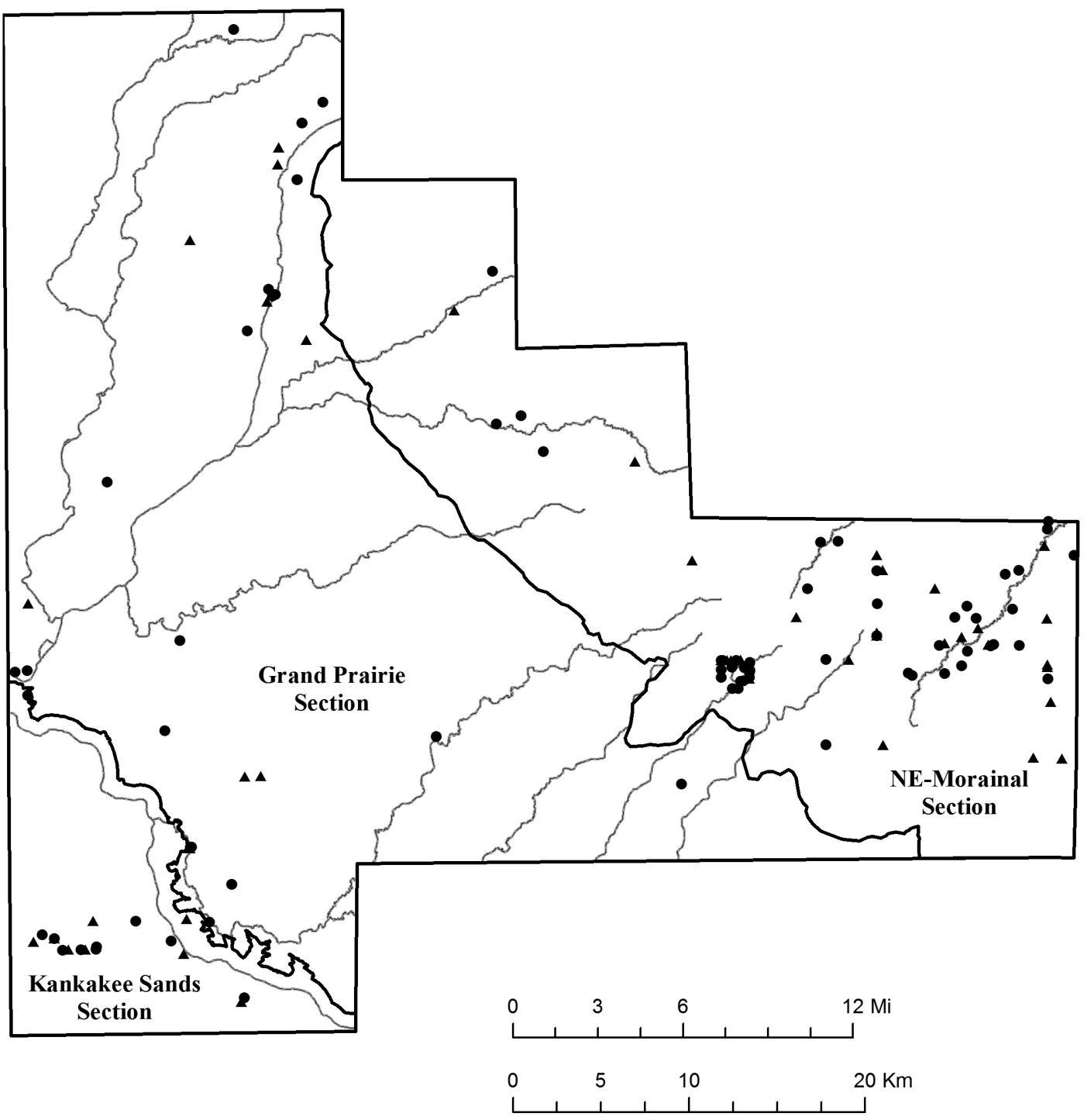

- Vouchered Record

- Unvouchered Record

Physiographic Section Boundary

Major Rivers \& Streams

Figure 2. Example of a widespread distribution pattern spanning all three physiographic sections, Thamnophis sirtalis. 
Table 4. Checklist of species in Will County for this and prior studies.

\begin{tabular}{|c|c|c|c|c|}
\hline Source: & $\begin{array}{c}\text { Schmidt \& } \\
\text { Necker (1935) }\end{array}$ & Edgren \& Stille (1948) & Smith (1961) & $\begin{array}{c}\text { This Study } \\
(1985-2010)\end{array}$ \\
\hline
\end{tabular}

Anura:

Necker (1935)

Edgren \& Stille (1948)

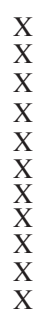

Acris crepitans

Anaxyrus americanus

Anaxyrus fowleri

Hyla versicolor

Pseudacris crucifer

Pseudacris triseriata

Lithobates blairi

Lithobates catesbeianus

Lithobates clamitans

Lithobates pipiens

Lithobates sylvaticus

\section{Caudata}

Ambystoma laterale

Ambystoma maculatum

Ambystoma texanum

Ambystoma tigrinum

Eurycea cirrigera

$\mathrm{X}$
$\mathrm{X}$

$\mathrm{X}$

$\mathrm{X}$

$\mathrm{X}$

X

$\mathrm{X}$

$\mathrm{X}$
$\mathrm{X}$

X

X

$\mathrm{X}$

$\mathrm{X}$

$\underset{X}{X}$

Hemidactylium scutatum

Necturus maculosus

Notophthalmus viridescens

\section{Testudines}

Apalone spinifera

Chelydra serpentina

Chrysemys picta

Clemmys guttata

Emydoidea blandingii

Graptemys geographica

Sternotherus odoratus

Terrapene carolina

Terrapene ornata

Trachemys scripta

Squamata - Sauria

Aspidoscelis sexlineatus

Ophisaurus attenuatus

\section{Squamata - Serpentes}

Clonophis kirtlandii

Coluber constrictor

Pantherophis vulpinus

Pantherophis spiloides

Heterodon platirhinos

Lampropeltis triangulum

Nerodia rhombifer

Nerodia sipedon

Opheodrys vernalis

Pituophis catenifer

Regina septemvittata

Storeria dekayi

Storeria occipitomaculata

Thamnophis proximus

Thamnophis radix

Thamnophis sirtalis

Sistrurus catenatus

Totals:

is

15

27

30

$\begin{array}{ll}X & X \\ X & X \\ & X \\ X & X \\ & X \\ X & X \\ & X \\ X & X \\ X & X \\ & X\end{array}$

$\begin{array}{cc} & X \\ X & X \\ X & X \\ X & X \\ X & X \\ X & X \\ & X\end{array}$

$\begin{array}{lll}X & & X \\ X & X & X \\ X & X & X \\ X & X & X \\ X & X & X \\ & X & X \\ X & & X \\ & & X\end{array}$

$\mathrm{X}$
$\mathrm{X}$

\begin{tabular}{lll} 
& $X$ & $X$ \\
$X$ & $X$ & $X$ \\
$X$ & $X$ & $X$ \\
$X$ & $X$ & $X$ \\
$X$ & $X$ & $X$ \\
$X$ & $X$ & $X$ \\
$X$ & $X$ & $X$ \\
$X$ & $X$ & $X$ \\
$X$ & $X$ & $X$ \\
$X$ & $X$ & $X$ \\
& $X$ & $X$ \\
$X$ & $X$ & $X$ \\
$X$ & $X$ & $X$ \\
$X$ & $X$ & $X$ \\
\hline
\end{tabular}

48 


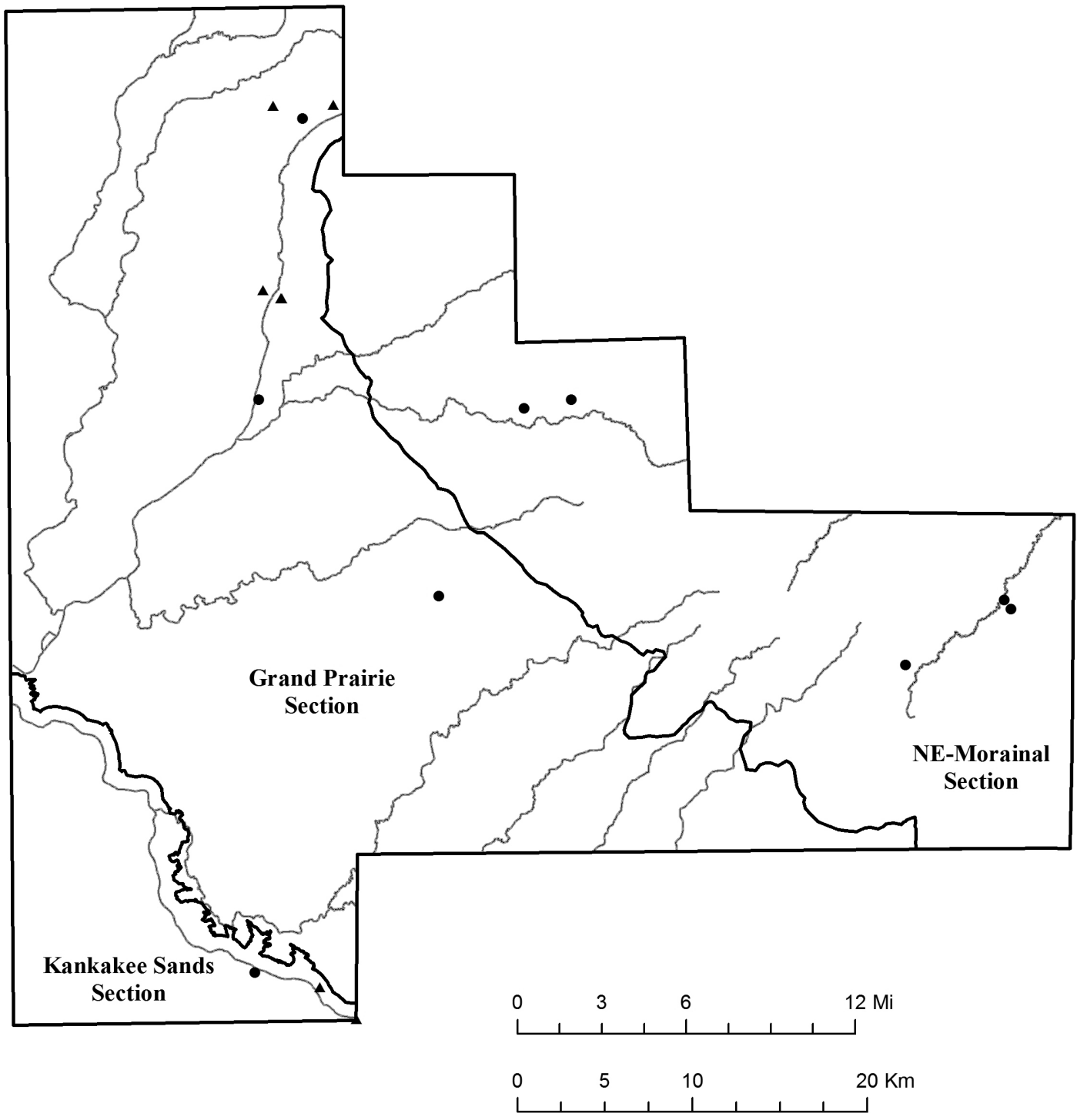

- Vouchered Record

- Unvouchered Record

— Physiographic Section Boundary

___ Major Rivers \& Streams

Figure 3. Example of a patchy distribution pattern spanning all three physiographic sections, Lampropeltis triangulum. 


\section{Patchy Species}

The distribution of the six patchy species spans all physiographic sections, but most are not abundant where they occur. Ambystoma tigrinum occurred at four large preserves in the Northeastern Morainal Section that were extensively surveyed, but were not abundant. They can be abundant in temporary ponds at some sand prairie/savanna preserves in the Kankakee Sands Section of southwestern Will County, and they were assigned locally common status.

Acris crepitans was widespread in presettlement times (Pope 1947; Smith 1961). Historic records exist from within the Northeast Morainal Section, but no extant populations were found since 1988. This suggests they were extirpated there and were confined to sections of the lower Des Plaines River drainage and the Kankakee Sands Section. Although prior surveys found them absent at two high-quality sand prairie and savanna preserves in the Kankakee Sands Section (O'Connell 1992), they are sometimes abundant at some former strip mine pits and reservoirs in the same area, as well as a few sites associated with the Des Plains River and Rock Run drainages in north-central Will County. In 2013, they were observed by the senior author in small to modest numbers at Braidwood Dunes and Savanna Nature Preserve at retention basins or sedge meadow and prairie marsh wetlands confined to the southwest side of the preserve. This suggests recent re-colonization of the preserve from nearby strip mine pits and reservoirs. Due to their scattered distribution and vulnerability to localized extirpation, cricket frogs were considered uncommon in Will County.

The distribution of L. blairi was centered to the south and west in Illinois (Brown and Morris 1990). In Will County, this species was documented from 10 widely scattered localities based on single individuals. They were apparently absent from the sand prairie and sand savanna preserves of the Kankakee Sands Section, but locally common at some strip mines across the county line in western Kankakee County. There was only one historic (1949; CA $15333,15336,15338)$ and one recent $(2002$;
INHS 18108) locality for this species within the Kankakee Sands Section. A 2013 survey that included the Braidwood preserve (unpublished data) documented numerous L. pipiens, but no L. blairi were encountered. There is one historic (1939, CA 7706) and only two recent (1988, 1991, DM unvouchered) localities for this species within the Northeastern Morainal Section. Considering the many surveys and attention that has been given to the eastern Will County preserves, the lack of additional records of $L$. blairi suggests the species is not established as self-sustaining populations. We propose that the plains leopard frog is expanding its range northeastward into Will County from Grundy and Kankakee counties, and possibly from the south in eastern Kankakee County.

Lampropeltis triangulum occurred in all three physiographic sections but was uncommon, with all 16 records based on single individuals (Fig. 3). They occur in the Kankakee Sands Section, but were not found in true sand prairie/sand savanna habitats. They were encountered only near forested areas along the Kankakee River. Its patchy distribution and lack of multiple captures suggests this species persists in low-density populations.

Regina septemvittata was recorded from all physiographic sections and was abundant in riverine marshes, backwaters, and tributaries at some localities along the Des Plaines River in north-central Will County, and along the Des Plaines and Kankakee rivers in southwest Will County. Because this species' distribution may not be continuous along the entire lengths of the Des Plaines and Kankakee rivers in Will County, we assigned it locally common status. A single historic record exists from Hickory Creek in the Northeast Morainal Section, but our surveys failed to yield recent records. This snake thrives in quarries and reservoir shorelines with exposed dolomite and shoreline vegetation. The distribution of $R$. septemvittata could be considered restricted, if later found to be confined to areas of adequate habitat along the DuPage, Des Plaines and Kankakee rivers.

Chelydra serpentina with only 15 widelyscattered localities, met the criteria of a patchy species. The paucity of vouchered records for 
this species may be because they are typically encountered as large adults, which are cumbersome to preserve as museum specimens. Also, more surveys in riparian areas or larger ponds and reservoirs would likely yield more records. Based on mark-recapture studies at some sites along the Des Plaines River, both large adults and juveniles occur in moderate numbers suggesting self-sustaining populations. They probably occur in the main channel of the Du Page, Des Plaines, and Kankakee rivers, as well as in larger quarries and reservoirs, mostly in the western half of the county. Snapping turtles probably persist in other smaller streams and backwaters associated with Hickory, Spring, and Plum creeks, and scattered reservoirs, quarries, and larger ponds in the eastern half of the county. More comprehensive turtle trapping surveys are needed countywide, and more effort in documenting large adults with unvouchered photo records would likely reveal that $C$. serpentina has a widespread pattern of distribution with common or locally common status.

\section{Restricted Species}

Nearly half (23 of 48) of the amphibians and reptiles have restricted distributions in Will County due to habitat or other ecological constraints. Some are on the periphery of their range, restricted to a specific physiographic section of the county, or associated with major pre-settlement landscape features, i.e., prairie and forest biomes. For example, Opheodrys vernalis was probably widespread in presettlement times, but loss of habitat to agriculture and urbanization, as well as intensive use of pesticides (Anton 1999; Smith 1961) has resulted in this species being restricted to only a few areas within the county. They are locally common in a few areas of the Northeastern Morainal Section and uncommon in at least one locality in the Grand Prairie Section associated with the Rock Run drainage. They may occur in prairie remnants, pastures and old field habitats within the Midewin Tallgrass Prairie, but limited effort within these landholdings prevents comment on its status. Based on the paucity of localities, $O$. vernalis warrants rare status in Will County.
Three amphibians and one snake are characteristic of eastern deciduous, northern mixed, and coniferous forest biomes that reach range limits in eastern Will County, and were restricted to forested areas in the Northeastern Morainal Section. Ambystoma laterale occurs in low numbers at Messenger Woods Nature Preserve in the Spring Creek drainage in Homer Township, but all four species reach their greatest abundance in forested areas of extreme eastern Will County along the Plum Creek and Thorn Creek drainages (Fig. 4). Ambystoma maculatum occurs in large numbers, with lessor numbers of A. laterale at Thorn Creek Woods Nature Preserve in eastern Will County. A two-year study by the senior author in 1993 and 1994 yielded 152 and 116 adult $A$. maculatum and 29 and 13 adults of $A$. laterale at a single breeding pond (Mauger and Robeson-Musial 2000). Pseudacris crucifer is locally abundant in forested areas along Plum Creek, but occurs sporadically farther west where a few individuals were heard calling less than $0.6 \mathrm{mi}$ from Thorn Creek Woods Nature Preserve. One individual heard calling within the preserve suggests a range expansion may be occurring.

Large areas of forest that occur today in eastern Will County that correspond to areas mapped as timber prior to settlement are the primary factor accounting for the observed distribution patterns of these species. Most forest in eastern Will County occurred in association with Plum Creek and Thorn Creek, and Hickory Creek and Spring Creek in north-central Will County. Post-settlement disturbances, including farming, grazing, logging, and development, and the subsequent loss of temporary breeding ponds, likely contributed to local extirpations and declines that resulted in the highly clustered localities observed today.

Storeria occipitomaculata is known from seven records in the Plum and Thorn Creek drainages. They are most consistently observed at the Lower Plum Creek Preserves at the WillCook County border at the IL-IN state line, and infrequently elsewhere. Smith and Minton (1957) considered it widespread but uncommon in Illinois; most Chicago region populations of this snake occur in widely separated forest 


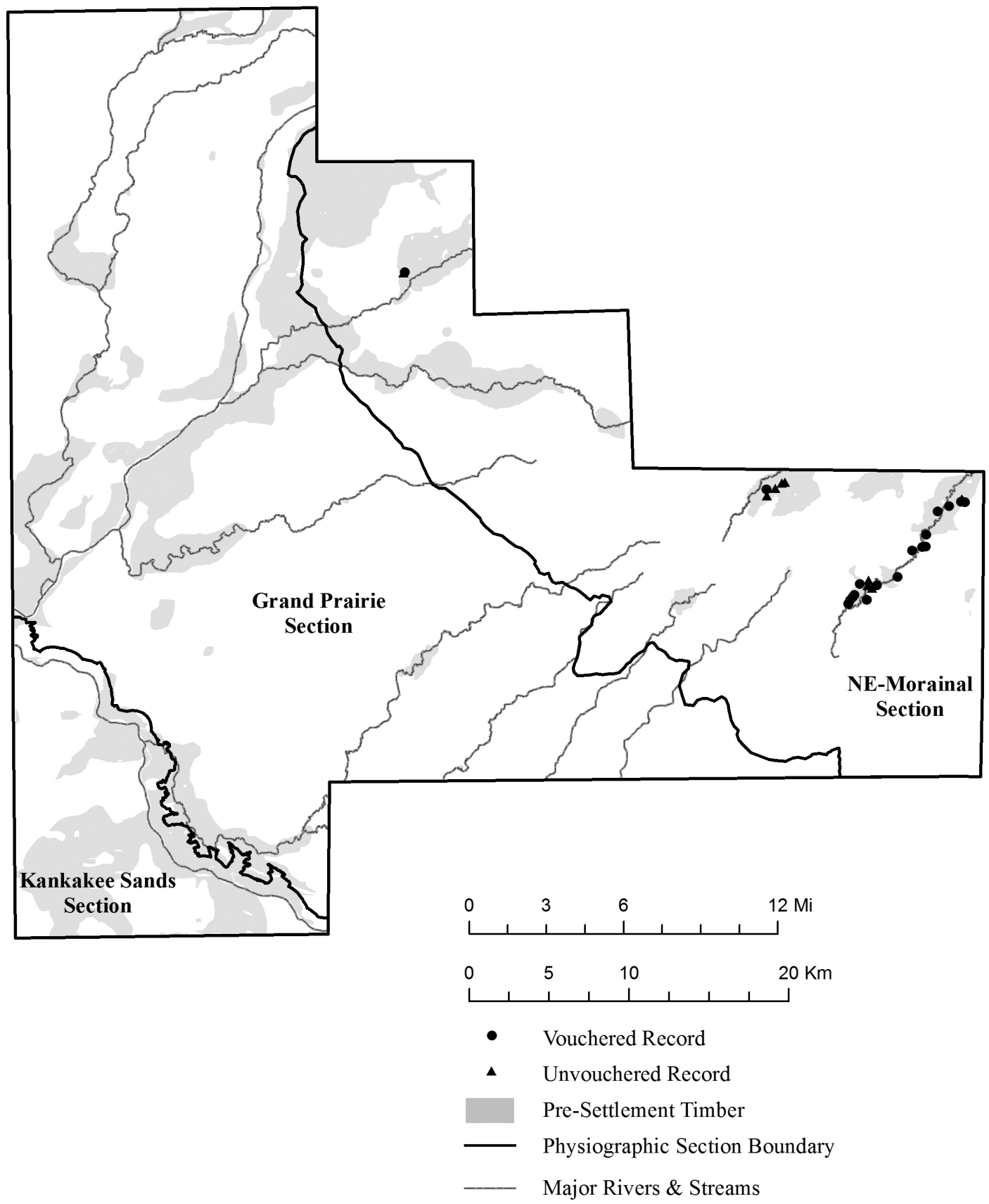

Figure 4. Example of a distribution pattern restricted to a single physiographic section. Ambystoma laterale is confined to forested areas along Plum, Thorn, and Spring creeks - all within the Northeastern Morainal Section. 
edge and old field habitats. Brown and Phillips (2012) suggested it had spread throughout the state, occupying many habitats and reaching its maximum distribution and abundance in Illinois by 1850 , with the reduction of its range commencing in 1860 from the deleterious effects of agriculture.

Hyla versicolor and Notophthalmus viridescens have restricted, bi-modal distributions in both eastern and southwestern Will County. Hyla versicolor (Fig. 5) can be locally abundant within the Plum and Thorn Creek drainages in eastern Will County, and at some of the sand prairie/sand savanna preserves of the Kankakee Sand Section in southwestern Will County. A few H. versicolor records extend northward into the Grand Prairie Section associated with the Forked Creek drainage and extreme lower Du Page River, but we have not found them farther north along the Des Plaines and Du Page Rivers, nor did they occur in the north and central regions of the county that were originally mapped as forest along Spring and Hickory creeks in the original land survey and today substantial remnants still persist.

Only two localities for $N$. viridescens are known; one at Braidwood Dunes and Savanna Nature Preserve in the Kankakee Sands Section (O'Connell 1992), and five records from a single locality at Thorn Creek Woods Nature Preserve in the Northeast Morainal Section. In 2013, two adults, including a breeding male, were captured at Braidwood preserve (unpublished data). This confirms that the species still occurs there, but like the eastern Will County population, probably persists in low numbers, surviving annual drought periods in the eft stage. The distribution of $N$. viridescens is highly restricted and the species is considered rare in Will County, echoing the findings of Smith and Minton (1957) who suggested that newts enter what is predominantly prairie landscape when circumstances are favorable.

Seven species have their range restricted entirely or mostly to the Kankakee Sands Section in southwestern Will County, including $A$. sexlineatus, $O$. attenuatus, $C$. constrictor, $H$. platirhinos, P. catenifer, T. proximus, and T. ornata. All seven reach their greatest abundance in true sand prairie and sand savanna habitats in southwestern Will County. All may have extended their range during the hypsithermal period ca 5,000 ybp (Smith 1957). There are a few records of $C$. constrictor and a single record of $H$. platirhinos extending northward into the Grand Prairie Section at the Des Plaines Conservation Area and Midewin National Tallgrass Prairie that are difficult to interpret, but it is unlikely either species occurs there in large numbers.

As of 2010, only three T. proximus had been found since 1986 at Braidwood Dunes and Savanna Nature Preserve, with a 2005 photo voucher of an adult male being the most recent record. However, in the 2013 survey of three sand area preserves, five T. proximus were observed; three by the senior author and two by others, one captured and photographed, the other found dead on the Exelon power-line right-of-way. All were in an area of low-lying sedge meadow and wet prairie-marsh in the southwestern portion of Braidwood Dunes and Savanna Nature Preserve (unpublished data).

Terrapene ornata is a xerothermic relict (Smith, 1957), reaching its easternmost distributional limit in the sand prairies of the Chicago region in Kankakee and Will counties. It is restricted to the Kankakee Sands Section and our records documented it at four localities in Will County. A Forest Preserve District of Will County one-day survey using tracking dogs failed to confirm its presence at two sites in 2012 and 2013. However, four individuals were captured in 2011 at a fifth locality unknown to us (Redmer 2012), and three more individuals were captured at this same site in 2013 (Dreslik 2013). Recent records for these surveys are not included in our database, but suggest the species persists in small numbers in at least three localities.

An observation of an adult T. ornata (unvouchered photo INHS-43014) in September 2013 at the Braidwood preserve is problematical because it had been previously surveyed with tracking dogs in 2012 and 2013 and none were found. The only prior record at the site was shell remains found in 1992, and no individuals were found in intensive fieldwork conducted at this site in 2013 (unpublished 


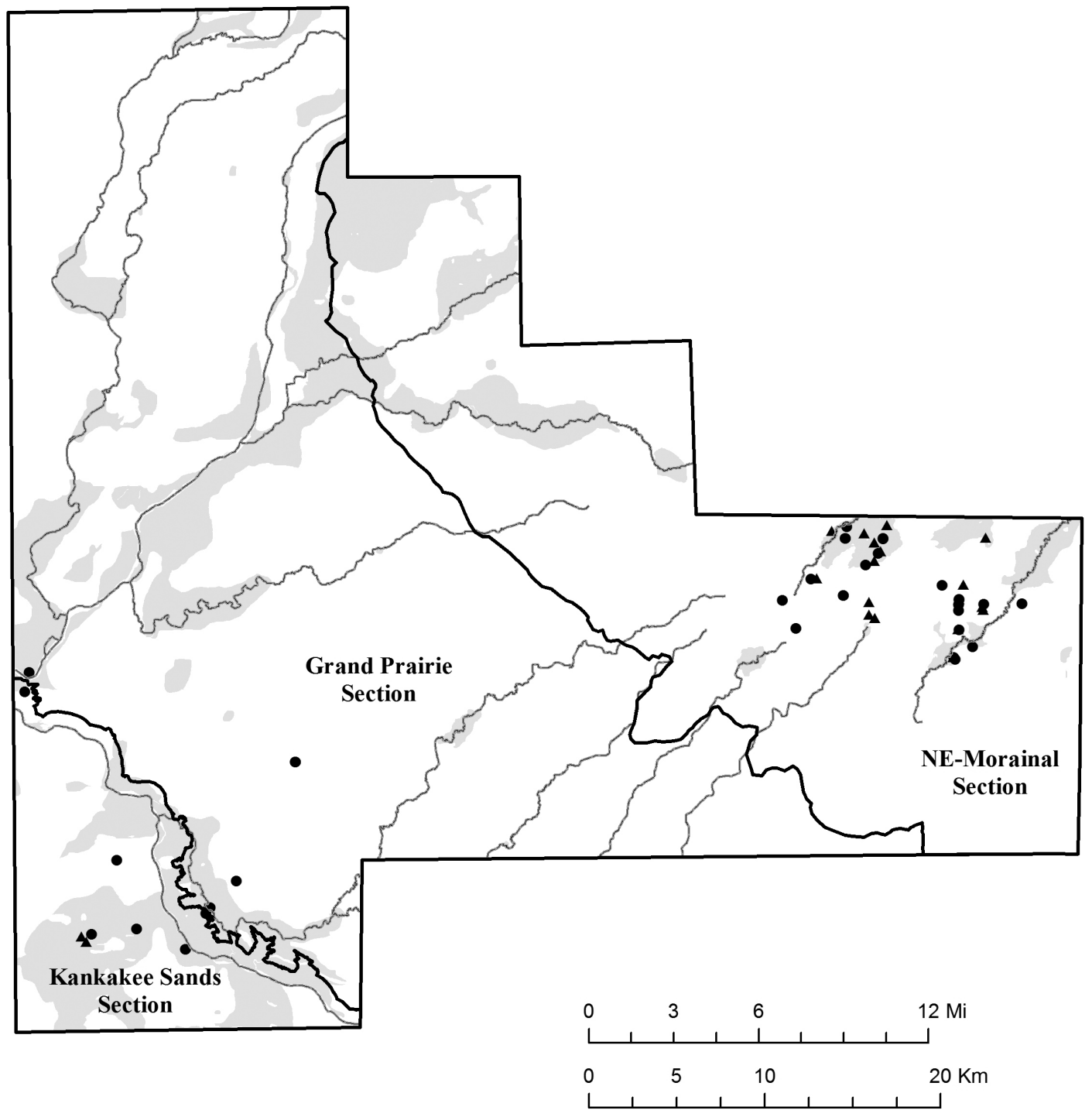

- Vouchered Record

- Unvouchered Record

Pre-Settlement Timber

Physiographic Section Boundary

Major Rivers \& Streams

Figure 5. Example of a restricted, bi-modal distribution pattern, Hyla versicolor, primarily constrained to far east and southwest Will County within the Northeastern Morainal and Kankakee Sands sections, with several outliers extending into the southwest Grand Prairie Section. 
data). This observation could be a captive release or a transient wandering into the preserve from another locality to the west/northwest. If a small relict population persists in the general area, the presence of a self-sustaining population within the preserve boundary is unlikely. The handful of individuals documented at only three localities suggests populations are small and highly vulnerable to extirpation.

Four amphibians considered relicts of past glaciation events have highly restricted distributions. Ambystoma texanum is known from three specimens (INHS 12589, 17525; FMNH 281630) and is confined to forested areas with a few upland ephemeral wetlands at McKinley Woods Forest Preserve in southwest Will County at the confluence of the Du Page and Des Plaines rivers near Channahon (Mauger and DalPonte 1998; Anton 2001). Although infrequently observed, egg masses ( $>50)$ were counted in one hour in 2002, and single individuals were observed since the discovery of the population from 1996 to 2010 in years that fieldwork was performed (Anton, unpublished data). Although Smith and Minton (1957) considered A. texanum an adaptable species, inhabiting such diverse habitats as dense forest and heavily farmed areas, our data suggest that $A$. texanum does not occur elsewhere in the area and is restricted entirely within the McKinley Woods Preserve.

Eurycea cirrigera is a southeastern species with a range extending into eastern Illinois, with a disjunct population within Kankakee River State Park (KRSP) in Will and Kankakee counties. This represents the northwestern most extent of its range, and it is isolated from the nearest population by $62 \mathrm{mi}(100 \mathrm{~km})$ southeast in Warren County, Indiana (Mierzwa 1989). Both E. cirrigera and A. texanum likely reached the northern limits of their ranges during the hypsithermal period, and were isolated as warming continued and the prairie biome expanded (Smith 1957; Mierzwa 1989; Boyle 2005). In Will County, E. cirrigera was confined to nine small spring/seep-fed drainages bisecting the Kankakee River Valley that flow over fractured dolomite bedrock and loamy sandy alluvial soil (Mauger et al. 2000;
Boyle 2005; Fig. 6). The species is also known from at least one site in KRSP farther east in Kankakee County (Mauger, unpublished data; Boyle 2005). A study of genetic variability of E. cirrigera populations in Aiken County, South Carolina, Warren County, Indiana, and Kankakee River State Park (KRSP) showed significant differences in microsatellite loci (Boyle 2005). Differentiation within KRSP samples yielded significant variability at three of seven loci including two of three sub-populations on the north and south sides of the Kankakee River, suggesting the river forms a barrier to gene flow (Boyle 2005).

Hemidactylium scutatum (IL-Threatened) is known from a single locality along Plum Creek within the Northeastern Morainal Section in far eastern Will County. It is a northern boreal forest species that reached its maximum distribution in Will County after the retreat of the glaciers forming the Tinley and Lake Border moraines. Smith and Minton (1957) considered it a generally distributed species in the Indiana Lake Plain and northeastern Illinois. Reproduction has been verified at the Will County site, but the population is small (Anton et al. 1998).

Lithobates sylvaticus is known from one preserve along Plum Creek. Adults have not been found and the record is based on two recent metamorph specimens (INHS 12023-4) found crossing a road at night during a rainstorm in 1995. Lithobates sylvaticus is also a northern boreal forest species that was probably more common prior to the retreat of glaciers (Smith 1957). Redmer (1998) considered $L$. sylvaticus to be peripheral in distribution with a fragmented range in Illinois; any populations remaining in Will County are relicts that became isolated and further restricted as boreal forest gave way to eastern deciduous forest and prairie. If a reproducing population still occurs in the area where the metamorphs were first documented, it must be small. Monitoring of the few potential breeding wetlands in the area has failed to document the presence of adults. As $L$. sylvaticus and $H$. scutatum are northern boreal species isolated in single populations that are small in size, and considering warming climate in our region, we predict that these two spe- 


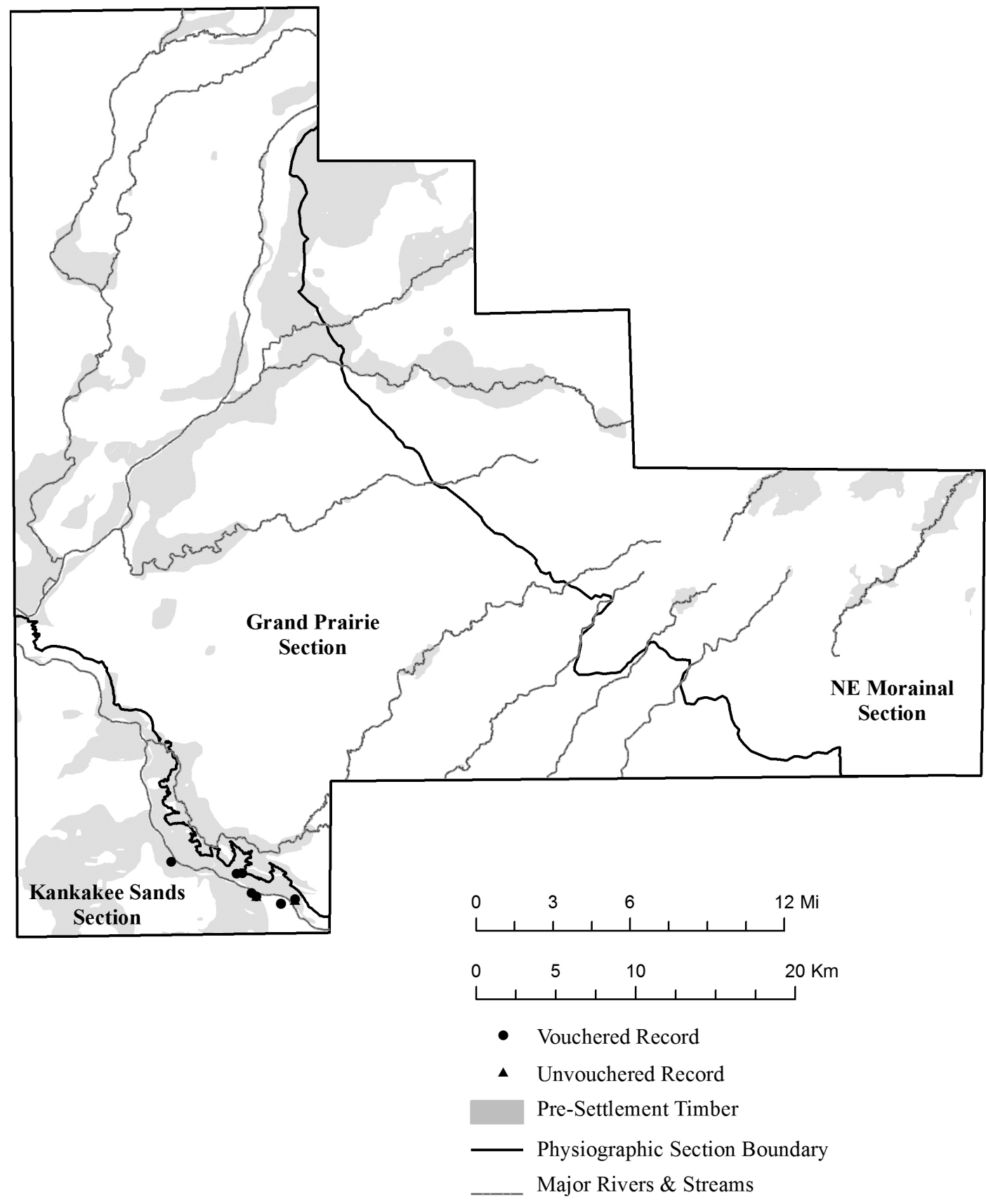

Figure 6. Example of a restricted distribution pattern of a glacial relict species, Eurycea cirrigera, all confined to groundwater-fed drainages that bisect the Kankakee River Valley wall within the Kankakee Sands Section. Note: not all 19 symbols display because some records are from the same location or site and symbols superimpose over one another. 
cies will eventually become extirpated in Will County.

Necturus maculosus (IL-Threatened) is extremely rare in Will County and restricted to the Kankakee Sands Section, where it persists in a tributary of the Kankakee River. Two of three records $(2004,2012)$ are from the same locality. It likely occurs within the main channel of the Kankakee River and possibly other nearby tributaries with clear, oxygenated water and abundant rock cover. A single historic (1949) record for Hickory Creek, originally cited at Joliet, turned out to be farther upstream near Pilcher Park, located within the Northeastern Morainal Section. Necturus maculosus was not encountered during an IDNR fish survey using electroshocking in May 1988 along a 5.1-mile section of Hickory Creek Forest Preserve from Schoolhouse Road to Route 45. During that survey, the senior author searched for mudpuppies under larger cobble and flagstones but found none. The state-endangered salamander mussel (Simpsonaias ambigua), relies on the mudpuppy as host for reproduction (Howard 1951), but only several common mussel species were found in Hickory Creek during the 1988 survey (unpublished data). No N. maculosus were found during a 2001 INHS survey that included seining Hickory Creek in the Mokena and Frankfort area (Cummings et al. 2002) or IDNR electroshocking surveys in 2006 and 2008 (R. Miller and B. Rung, pers. com). Habitat degradation since 1949 is likely responsible for its extirpation from Hickory Creek and probably from the Des Plaines and Du Page drainages in Will County. Necturus maculosus was probably more widespread prior to extensive stream modification, subsequent water quality decline, and loss of headwater or gravel/riffle-bar breeding habitat (Phillips et al. 1999). Continued survey efforts focusing on the Kankakee River and its tributaries are recommended.

Clemmys guttata (IL-Endangered) is known from three localities in the Grand Prairie Section. Only two populations persist - a smaller, isolated third population was extirpated in conjunction with expansion of a nearby limestone quarry. Population censuses conduct- ed by the senior author between 1990 and 2008 indicated that both populations were reproducing but extremely small ( $<150$ individuals), and considered highly vulnerable to extinction due to stochastic processes (unpublished data/ reports).

Emydoidea blandingii (IL-Endangered) is known from 29 records and 11 localities within the Grand Prairie and Kankakee Sands sections, with the majority in the former. Extensive mark-recapture and radio-telemetry studies conducted on this species at several localities indicated that at one site the population is small and has a $27.5 \%$ chance of extinction within 50 years, with some adults ranging widely, often outside preserve boundaries (Banning et al. 2006; Anthonysamy 2013). There are six records from two localities in our database for the Kankakee Sands Section. Its presence at one of these localities was reconfirmed in a 2013 survey based on the capture of seven adults (four males and three females; unpublished data). All seven were large, older adults and the population appears to be small with no evidence of successful reproduction. Wetland habitat is limited where this species occurred in the Kankakee Sands Section and we suggest that these populations have a high risk of extirpation

Sistrurus catenatus (IL-Endangered) is restricted to the Northeastern Morainal Section, where historic and recent records confine it to extreme eastern Will County south of Crete. In 1986, a DOR S. catenatus was given to the FPDWC. The specimen was inadvertently disposed of while in freezer storage, but the record resulted in a recommendation to conduct future surveys (Mauger 1986). Although initial surveys conducted in 1990 and 1991 failed to find this species (Strond 1992), two individuals were found in September 1992 by the senior author and documented with photos. A markrecapture and radio-telemetry study began in May 1993, and concluding with spring emergence and monitoring in April-May of 1994, confirmed the presence of a small population estimated at less than 40 individuals (Mauger and Wilson 1999). Capture rates of individuals over subsequent years showed a marked de- 
cline, and after eight years of spring emergence surveys, no live individuals have been found at the site since 1996, the last being a DOR specimen (INHS 15102) recovered in 1999 (Dreslik et al. 2006; Mauger 1999).

Fourteen historic records (five unvouchered, nine vouchered), and surveys conducted since 1986, suggested that $S$. catenatus occurred over a much broader area in the CreteGoodenow region, but habitat destruction, fragmentation, and natural community succession reduced the local population to ever smaller patches of habitat, with a corresponding reduction in numbers of individuals encountered (Mauger and Wilson 1999). Population viability analysis results demonstrated rapid decline for this population, with the model predicting median time to extinction at eight years in 2002 , three years after the last $S$. catenatus was found (Dreslik et al. 2006). We suggest that $S$. catenatus has been extirpated in Will County.

Clonophis kirtlandii (IL-Threatened) is known from 39 records at 2 localities within the Northeastern Morainal Section in extreme eastern Will County. Although initial records of $C$. kirtlandii were obtained during surveys for $S$. catenatus conducted from 1992-1995, surveys targeting the fossorial and ecologically sensitive $C$. kirtlandii were started in 1996 and continued through 2007 (Anton 2007). These surveys focused on areas of perched water tables in wet prairie or old-field habitats with an abundance of crayfish burrows (Cambarus diogenes, Fallicambarus fodiens, and Procambarus gracilis), which form critical microhabitat for foraging, shelter, and hibernation. Clonophis kirtlandii is a northern species with relict southern populations (Smith, 1957). Considered endemic to the Prairie Peninsula, $C$. kirtlandii was thought to be a xerothermic relict by Schmidt (1938) and Conant (1943), who suggested that it expanded its range westward and persisted in the Prairie Peninsula following the xerothermic period, but was extirpated elsewhere within its range.

Clonophis kirtlandii was also considered a glacial relict by Thomas (1951), who asserted that it survived the glacial advance near the ice front and re-colonized glaciated areas following ice retreat. Although cryptic habits and a low rate of recaptures make it difficult to assess population size in this species, small numbers are consistently captured using cover board arrays. At one site in eastern Will County, C. kirtlandii appears to persist across several patches of habitat and may be benefiting from site management aimed at restoration of prairie and wetland hydrology (Anton 2007).

\section{Undetermined Species}

Records of four species, including T. carolina, $P$. spiloides, $N$. rhombifer, and A. fowleri (Table 1) lacked any historic records that would provide evidence that these species were native to Will County. Anaxyrus fowleri is based on a specimen (INHS 19127) taken at Lockport Prairie Nature Preserve in the Grand Prairie Section in 2003 and was one of three heard calling that year. Efforts to reconfirm their presence using calling frog surveys in subsequent years failed to reconfirm its presence. Introduction by humans is the most likely explanation for this record since this preserve has been the site of detailed studies for 20 years (1988-2008). There are no historic records of this toad anywhere in Will County and efforts to document their presence at preserves in the Kankakee Sands Section of southwestern Will County along the Grundy-Will County line, or southeastern Will County along the KankakeeWill County lines were unsuccessful.

Anaxyrus fowleri is common to the southeast in Kankakee County in Pembroke and St. Anne townships (Mauger and Anton 2003), and are known from adjacent Grundy County. The northernmost limit of A.fowleri in the Chicago region, based on calling surveys, is extreme northwestern Pembroke Township, $3.2 \mathrm{mi}$ (5.1 $\mathrm{km})$ south of the Kankakee River and ca. 13 mi $(20.9 \mathrm{~km})$ south of the Will County line in Kankakee County. The westernmost range limit in Kankakee County was on the west side of the Iroquois River in extreme eastern Otto Township, $14.3 \mathrm{mi}(23.0 \mathrm{~km})$ southwest of the Will County line, 21-23 mi (33.8-37.0 km) southeast of the nearest Will County sand area preserves near Braidwood, and more than 39 
mi $(62.8 \mathrm{~km})$ southeast of the Lockport Prairie Preserve (Mauger and Anton 2003). Despite the single specimen, subsequent surveys indicated no extant, reproducing populations and the species is not considered part of the Will County fauna.

Fifteen records of $T$. carolina are restricted to extreme eastern Will County in the Plum Creek watershed. An adult was captured in 2013 in an aquatic turtle trap at Braidwood Dunes and Savanna Nature Preserve and is believed to have been a captive release; there is no historic evidence T. carolina is native to the sand prairie and savanna habitats within the Kankakee Sands Section. Since no historic records for this species exist in Will County, and all individuals documented were adults, we cannot document the presence of a reproducing population. However, at least one of our specimens from Will County was gravid, and an individual found in Cook County just across the Will County line was radiographed and also determined to be gravid.

The senior author observed two adult $T$. carolina killed in a controlled burn at Hoosier Prairie near Griffith, Lake County, Indiana in the spring of 1984. The preserve is $7 \mathrm{mi}$ (11.3 $\mathrm{km}$ ) northeast of the nearest Will County records, but efforts to confirm present-day occurrence there through consultation with Indiana DNR staff failed to provide any evidence that a self-sustaining box turtle population occurs there. Although Hoosier Prairie could be a source of individuals for eastern Will County, it is highly unlikely that they could successfully cross US Route 30, and numerous other busy roads in the region. Genetic analysis comparing Will County individuals with the nearest populations in northwest Indiana may provide insight into whether or not Will County individuals should be considered native, westward range expansions. In the absence of genetic or other evidence, we cannot rule out the possibility that these records resulted from the release of captive or translocated individuals.

Two records of $P$. spiloides were based on a single 1993 specimen (INHS 11186) found at Thorn Creek Woods and an observation of a large adult accompanied by a photo in 2010 at the Environmental Learning Center in Hickory Creek Forest Preserve in the Frankfort-Mokena area. Efforts to find additional specimens at Thorn Creek Woods in the mid-1990s were unsuccessful. In addition to an intensive reptile and amphibian survey conducted in 1988, repeated visits to Hickory Creek Preserve by the senior author between 1986 and 2007 did not produce any observations or records of $P$. spiloides. Many of the roads that bisect or parallel the preserve are heavily traveled, yet no DORs have been reported. The two records that have been documented may be of released or escaped captive specimens. As we were unable to corroborate additional records of this large snake that would indicate presence of a selfsustaining population, we consider $P$. spiloides to be of questionable status in Will County.

In 2009, two N. rhombifer were collected at the Isle a la Cache Museum parking lot near Romeoville. The first was found dead and salvaged (INHS 21384). A smaller, emaciated specimen was captured the next day, photographed, and released. The facility is located on an island in the Des Plaines River adjacent to the I \& M Canal. The northernmost range limit of this large aquatic snake is Woodford County, ca. $113 \mathrm{mi}(181.8 \mathrm{~km})$ southwest of the Will County line (Phillips, et al. 1999). Two anecdotal reports of this southern species from La Salle and Marshall counties along the I \& M Canal and Illinois River have not been confirmed with specimens or photos. Given the considerable distance to the nearest known populations and intensive survey efforts that have occurred over the past decade at numerous preserves along the Des Plaines River, we consider this record problematical. It may represent released individuals, but we cannot rule out a northeastward range expansion occurring along the Des Plaines and I \& M Canal corridor, originating from the Illinois River, following the logic of Smith (1957:213), and Smith and Minton (1957:345). However, a 2014 survey in which both authors participated at McKinley Woods Forest Preserve that included the I \& M Canal, only N. sipedon were encountered. Until additional records including reproductive females or neonates indicative of a self-sustaining 
population, we consider $N$. rhombifer a species of questionable occurrence in Will County.

Four turtles, including A. spinifera, G. geographica, $S$. odoratus, and $T$. scripta have insufficient numbers of records for us to reliably assess distribution. All four are known to prefer large river systems or backwaters and marshes associated with large rivers. We initially had no records for T. scripta for the Kankakee Sands Section, but two large adult females and a juvenile caught in turtle traps at Braidwood Dunes Preserve in 2013 indicate the species is present and reproducing. Trachemys scripta occurs in the large reservoirs and strip mine pits in the area, especially the Mazonia Fish and Wildlife Area south of the Braidwood Dunes Preserve, and they have been observed in the main channel of the Kankakee River. Apalone spinifera, G. geographica, and T. scripta also colonize quarries and large reservoirs, with Lake Renwick Heron Rookery Nature Preserve in Plainfield having both A. spinifera and $G$. geographica. Additional trapping effort and mark-recapture surveys in these habitats may reveal a patchy distribution pattern and locally common status for these species.

All six records of $S$. odoratus occurring in the Grand Prairie Section were associated with riverine marshes and backwaters along the Des Plaines River and Rock Run in Joliet. The paucity of records for $S$. odoratus is attributable to its cryptic habits, and intensive trapping surveys are required to establish its presence. The 2014 survey at McKinley Woods Forest Preserve included hoop-net trapping that captured two adult males in a large, backwater bay of the I \& M Canal. These data and the six prior records suggest it to be restricted to the backwaters, sloughs, marshes, or shallow ponds along the Des Plaines, Du Page and Kankakee rivers in western and southwestern Will County.

In 2002 a single Sinaloan milk snake (Lampropeltis triangulum sinaloae; INHS 18558), was found DOR on Manhattan-Monee Rd east of Manhattan by the senior author. In 1990, an adult tokay gecko (Gekko gecko) was found DOR on Caton Farm Rd. west of Rt. 59 near Plainfield (J. C. Murphy, pers. comm. 2014). Both were considered escaped captives.

\section{Potentially Occurring Species}

The Graham's crayfish snake (Regina grahamii) is documented by one 1940 Cook County specimen (FMNH 35148) originally labeled Will County, and described it as coming from "S of Matteson on Rt. 49" in an area then referred to as "Matteson Swamp." A review of U.S. Geological Survey topographic and wetland maps suggests remnants of these wetlands still exist in extreme southern Cook County, ca. $1.6 \mathrm{mi}(2.6 \mathrm{~km})$ from the Will County line. Two site visits by us in 2011 revealed the presence of small amounts of suitable habitat, but intensive surveys for this snake have not been performed. Because the specimen originated in Cook County, we omitted it from our database and the current list of Will County herpetofauna. There are a few areas of potential habitat in Will County south of Matteson, but it is unlikely these sites are large enough to sustain populations. Until more detailed survey work is conducted at these localities and recent records are obtained, we cannot consider it part of the Will County fauna.

The red-backed salamander (Plethodon cinereus) is considered a peripheral species to Will County; several localities yielding multiple individuals were found across the IL-IN state line in Indiana, $2.4 \mathrm{mi}(3.8 \mathrm{~km})$ east of the Will County line (D. Beamer, pers. comm.). Searches of suitable habitat in the Plum Creek drainage were unsuccessful; due to a lack of specimens it is not included in the list of Will County herpetofauna. Future surveys may detect this species in pockets of forested habitat not currently owned by FPDWC farther east and close to the IL-IN state line.

\section{ZOOGEOGRAPHY}

The herpetofauna of Will County is currently the most diverse in northeastern Illinois. According to Smith (1957) and Smith and Minton (1957), the modern-day fauna of Illinois has been profoundly shaped by the ecological tolerances of various species, the diversity of habitats, and the glacial and climatic history of the region. Following the retreat of the Wis- 
consinan ice fronts, the region was re-colonized by a northward advancing flora and fauna. This glacial retreat was not continuous and was punctuated with numerous episodes of minor re-advances and retreats that yield a complexity of modern-day reptile and amphibian fauna consisting of species with northern, eastern, southern, or western affinities. We concur with Brown and Phillips (2012) that the modern herpetofauna was established in the Great Lakes Region by 6,000-4,000 YBP and that the expansion of the Prairie Peninsula at its Hypsithermal peak would not have been a significant barrier to most species. The Prairie Peninsula, a complex landscape mosaic of prairie and forest and corridors of forest along major rivers and streams, would have served as dispersal corridors or refugia for species adapted to forest or its ecotone.

Will County has a complex glacial history that has resulted in a diverse landscape with sand prairie and savanna in the southwest within the Kankakee Sands Section, and eastern deciduous forest predominantly confined to bands along major riparian areas within the Grand Prairie and Northeastern Morainal sections. Thus, the DuPage, Des Plaines, and Kankakee rivers and their tributaries would have provided major corridors for dispersal during post-glacial recolonization. These influences are readily apparent with southern or western species including $T$. ornata, $H$. platirhinos, $P$. catenifer, $T$. proximus, A. sexlineatus, and $O$. attenuatus, all restricted to the sand prairie and savanna habitats in the Kankakee Sands area. The dispersal of these species probably reached its maximum during the Xerothermic (Hypsithermal) period about 5,000 YBP. Conversely, southern species such as E. cirrigera and A.texanum would have extended their ranges into Will County far earlier when mesophytic forest had reached its maximum development, then confined to their present-day refugia as the climate warmed and the prairie expanded.

Species with northern or eastern affinities such as P.crucifer, A. laterale, and A. maculatum today are restricted to eastern Will County and would have reached their peak distribution as the eastern deciduous forest reached its max- imum westward extent. These species could have extended farther west into the Grand Prairie Section and it is possible that postsettlement logging and draining of wetlands led to extirpation in these areas. Other northern/ eastern species such as L. sylvaticus and $H$. scutatum were probably early post-glacial arrivals. As the climate warmed and the prairie expanded, they were likely further restricted in occurrence, and today they occur as single, relict populations in far eastern Will County.

Other northern/eastern species including $N$. viridescens and $H$. versicolor have bimodal occurrences, being restricted to the Kankakee Sands Section (with outliers of $H$. versicolor extending into the far southwest Grand Prairie Section) and the far east Northeastern Morainal Section. This suggests there were two pathways of re-occupation, one from the northeast with the advance of deciduous forest, and another eastward extension along the Kankakee River corridor. Both species also would have incurred noticeable declines with the conversion of prairie and drainage of wetlands, especially prairie and wetlands in close proximity to the forested areas.

Species typically associated with prairie such as $O$. vernalis, $S$. catenatus, and E. blandingii were probably more widespread across Will County in pre-settlement times and reduced to relict populations through agriculture, mirroring the dynamics proposed by Brown and Phillips (2012) for S. occipitomaculata. A similar scenario might apply to $C$. guttata, which may have been more widespread in western Will County in prairie, sedge meadow, and marsh wetlands within and near the Des Plaines River Valley. In Indiana, the distribution of $C$. guttata occurs in the far northern one-fourth of the state (Minton 2001) and the author is aware of the species occurrences in dune and swale habitat near Gary and in wetland complexes within the Indiana Dunes National Lakeshore. There are three historic records in northeastern Illinois in the Chicago Lake Plain in Cook County, two of them near the IL-IN state line at Wolf Lake, and the other near Palos Park in proximity to the Des Plaines River Valley (Mauger 1988). This suggests that dispersal of C. guttata may have extended from northwest 
Indiana through the Chicago Lake Plain, then southward along the Des Plaines River Valley. Urban and industrial development within the Chicago Lake Plain and along the Des Plaines River resulted in the two isolated, relict C. guttata populations that exist in western Will County. The upland prairie and savanna would likely have been barriers for $C$. guttata in dispersal westward into eastern Will County from northwest Indiana. Although, $C$. guttata could have been more widespread in the prairie marshes and sedge meadows throughout the Northeastern Morainal and Grand Prairie sections, and extirpated as the prairie and wetlands were converted for agriculture, there is no way to assess this latter possibility today.

The network of major rivers and streams permeating Will County served as dispersal corridors for riverine species such as $A$. spinifera, C. serpentina, G. geographica, $T$. scripta, N. sipedon, R. septemvittata, and $N$. maculosus. Degradation of water quality and other factors likely account for declines and the current restriction of $N$. maculosus to a tributary of the Kankakee River. We think it likely that N.maculosus still occurs within portions of the main channel of the Kankakee River.

Widespread and common species including A. americanus, $P$. triseriata, $L$. catesbeianus, L. clamitans, L. pipiens, C. picta, P. vulpinus, $S$. dekayi, $T$. radix, and $T$. sirtalis probably experienced range restrictions as settlement progressed, but their wider ecological tolerances enabled them to persist in human-altered landscapes. Some such as A. americanus, $C$. picta, and L. catesbeianus have noticeably increased their occurrence by taking advantage of man-made wetlands such as reservoirs and stormwater retention ponds.

Complicating our analysis, and that of Brown and Phillips (2012), is the difficulty in interpreting the distributions of peripheral or rare species, because no comprehensive historic data exist for Will County and the Chicago region before the time of Robert Kennicott, when conversion of most prairies in the state to agriculture commenced. Very few museum specimens prior to 1860 exist, and Will County records since Garman (1892) are scant and/ or anecdotal. Schmidt and Necker (1935) and
Edgren and Stille (1948) reported 15 and 27 species, respectively, for Will County. For most of these species we have sufficient survey effort and records since 1985 to reasonably interpret present-day distribution and status despite the paucity of historic records. Species that lack sufficient historic records (T. carolina, $P$. spiloides, and $N$. rhombifer) will require more surveys before a definitive statement of their recent distribution and status can be made.

\section{CONSERVATION AND MANAGEMENT}

\section{All habitats in Will County have been altered} through various forms of human development, which may negatively impact isolated and/ or less vagile amphibian and reptile populations. Some smaller FPDWC preserves or those isolated by development or having inferior habitat quality were assigned low survey priority, and may lack current records of common or widespread species that are presumed to occur there. Although Morris et al. (1983) reported a statewide decline in all amphibians and reptiles, there is insufficient data to chronicle declines for many species. However, our work suggests that several amphibian species have declined, are extirpated, or have high potential risk for extirpation. The isolated population of $\mathrm{H}$. scutatum is bordered on two sides by residential property and would appear to be at risk from herbicide and fertilizer runoff from yards that adjoin the population's primary breeding pond. Some of these species may have never been widespread or common within the section (e.g., $N$. maculosus, $R$. septemvittata, and L. blairi), while others were restricted in occurrence due to the drainage of wetlands and conversion of prairie to agriculture.

A similar scenario may apply to some species restricted to areas within the Kankakee Sands Section. Certainly T. ornata may have been more widespread and its range might have extended farther north and east into the black soil prairies within the Grand Prairie and Northeastern Morainal sections, only to succumb to agriculture. Other sand-area species such as $A$. sexlineatus, $O$. attenuatus, $C$. constrictor, $H$. platirhinos, P. catenifer, and $T$. proximus are also more isolated and restricted 
to a handful of preserves or persist in habitat remnants along railroad rights-of-way. Several sub-populations of E. cirrigera confined to seep-fed drainages that bisect the Kankakee River Valley bluff receive run-off from agricultural land in adjacent upland may be at risk from water quality degradation from residues of fertilizers, herbicides, or pesticides.

Several FPDWC preserves support populations of rare, uncommon, or state-listed species, The discovery of new populations of all amphibians and reptiles, including species not previously known to occur in the county, is possible. Paradoxically, such discoveries may occur as a result of surveys conducted for mitigation purposes in support of development projects, which continue in Will County, one of the most rapidly urbanizing counties in the Chicago region (http://quickfacts.census.gov/ qfd/states/17/17197.html).

The FPDWC continues to acquire land through county bond referenda, and manage the land according to mixed-use guidelines (i.e., human recreation, conservation, and protected natural areas). Increasingly, however, management of isolated fragmented habitats supporting the FPDWC's diverse herpetofauna will depend on linking sites, either through management partnerships with railroad, power, or other infrastructure agencies or companies, or the continued acquisition of land along riparian corridors, such as the Des Plaines Du Page and Kankakee rivers, and the I\&M Canal.

Research on the current distribution, abundance, population dynamics, and the conservation and management of amphibians and reptiles in Will County continues. A logical next step would be to use the results of our study to assess the conservation importance of these species on a countywide basis. We proposed that a Herpetofaunal Quality Index (HQI) modeled after the Floristic Quality Assessment (Swink and Wilhelm 1994; Taft et al 1997) and Index of Biotic Integrity (IBI; Karr et al. 1986) would be a useful tool for rating natural areas for herpetofaunal diversity and importance, and as a vehicle in prioritizing land acquisitions and management and restoration activities (Mauger and Anton 2006). Chicago Wilderness formed a partnership with regional herpetologists to assist in developing a similar HQI applicable across the Chicago Region in 2002 that culminated in a pilot study testing a modified version of our original index (Brodman et al. 2005). The HQI has the potential to assist the FPDWC or other forest preserve districts within the region in rating the quality and/or importance of preserves as well as to indicate ecosystem health and integrity as alteration of the landscape continues.

The Will County herpetofauna remains diverse despite extensive post-settlement alteration and destruction of most habitat types. Global climate change may influence both region-wide range contractions of some sensitive, rare, and restricted species, and facilitate expansion of disturbance-tolerant southern species along riparian corridors from counties to the southwest in the future. Hopefully, such losses will be mitigated by the ongoing acquisition, restoration, and management of remaining natural communities by the efforts of the Forest Preserve District of Will County, Illinois Department of Natural Resources, USDA Forest Service, and municipal park districts. 


\section{LITERATURE CITED}

Anthonysamy, W.J.B., M.J. Dreslik, and C.A. Phillips. 2013. Disruptive influences of drought on the activity of a freshwater turtle. The American Midland Naturalist 169:322-335.

Anton, T.G., D. Mauger, R.A. Brandon, S.R. Ballard, and D.M. Stillwaugh, Jr. 1998. Distribution, habitats, and status of the four-toed salamander Hemidactylium scutatum (Caudata: Plethodontidae) in Illinois. Chapter 6 in M.J. Lannoo, ed. Status and conservation of midwestern amphibians. University of Iowa Press, Iowa City

Anton, T.G. 1999. Current distribution and status of amphibians and reptiles in Cook County, Illinois. Transactions of the Illinois State Academy of Science 92(3-4):211-232.

Anton, T.G. 2001. Additional herpetofauna surveys of McKinley Woods, Channahon Township, Will County, Illinois. Unpublished report to the Forest Preserve District of Will County. 10 pp.

Anton, T.G. 2007. Status surveys for the Kirtland's snake, Clonophis kirtlandii (Colubridae: Natricinae), and eastern massasauga, Sistrurus catenatus (Viperidae: Crotalinae) at Goodenow Grove Nature Preserve, Will County, Illinois. Unpublished report to the Forest Preserve District of Will County. 15 pp.

Banning, W.J, M.J. Dreslik, and C.A. Phillips. 2006. Continued study of the ecology of the freshwater turtle community at Lockport Prairie Nature Preserve: with special emphasis on Blanding's turtle (Emydoidea blandingii). Illinois Natural History Survey, Center for Biodiversity Technical Report 2006 (4):1-259.

Bavetz, M. 1994. Geographic variation, status, and distribution of Kirtland's snake (Clonophis kirtlandii Kennicott) in Illinois. Transactions of the Illinois State Academy of Science 87(3-4):151-163.

Boyle, M. 2005. Genetic distinctiveness of a peripheral Illinois population of the southern two-lined salamander (Eurycea cirrigera). MS thesis, Chicago State University. 24 pp.
Brodman, R., T.G. Anton, K. Glennemeier, P. Seth, D. Didion, and A. Luksus. 2005. Status of amphibians and reptiles in savanna habitats and savanna mosaic communities of the Chicago Wilderness Region. Chicago Wilderness Journal 3(2):38-44.

Brown, L.E., and M.A. Morris. 1990. Distribution, habitat, and zoogeography of the plains leopard frog (Rana blairi) in Illinois. Illinois Natural History Survey Biological Notes $136.6 \mathrm{pp}$.

Brown, L.E., and C.A. Phillips. 2012. Distribution, habitat, and zoogeography of the semifossorial red-bellied snake Storeria occipitomaculata (Storer) in Illinois. Illinois Natural History Survey Bulletin 39(5):297-322.

Conant, R. 1943. Studies on North American water snakes I: Natrix kirtlandii (Kennicott). American Midland Naturalist 29:313-341.

Cummings, K.S., C.A. Phillips, C.A. Mayer, and J.E. Petzing. 2002. Status survey for the mudpuppy, Necturus maculosus (Amphibia: Proteidae) and salamander mussel, Simpsonaias ambigua (Mollusca: Unionidae) in Illinois. Illinois Natural History Survey, Center for Biodiversity Technical Report 2002 (2). 18 pp.

Dreslik, M.J., S.J. Baker, and C.A. Phillips. 2006. Survey for the state endangered eastern massasauga rattlesnake (Sistrurus catenatus) in the Chicagoland region: field surveys from 2005-2006 and historical occurrence. Unpublished report to the Illinois Department of Natural Resources. Illinois Natural History Survey, Center for Biodiversity Technical Report 2006 (10):1-73.

Dreslik, M.J. 2013. Threatened and endangered species annual activity report: 2013, Permit \#0511S. Unpublished report to the Forest Preserve District of Will County.

Edgren, R.A., and W.T. Stille. 1948. Checklist of Chicago area amphibians and reptiles. Chicago Academy of Sciences Natural History Miscellanea 26:1-7.

Garman, H. 1892. A synopsis of the reptiles and amphibians of Illinois. Illinois Laboratory of Natural History Bulletin 3(13):215-388. 
Harding, J.H. 1997. Amphibians and reptiles of the Great Lakes region. University of Michigan Press.

Heyer, W.R., M.A. Donnelly, R.W. McDiarmid, L.C. Hayek, and M.S. Foster. 1994. Measuring and monitoring biological diversity: standard methods for amphibians. Smithsonian Institution Press. 364 pp.

Howard, A.D. 1951. A river mussel parasitic on a salamander. Chicago Academy of Sciences Natural History Miscellanea 77:1-6.

Illinois Department of Natural Resources. 1996. Illinois land cover: an atlas. Illinois Department of Natural Resources, Springfield. IDNR/EEA96/05.

Karr, J.R., K.D. Fausch, P.L. Angermeier, P.R. Yant, and I.J. Schlosser. 1986. Assessing biological integrity in running waters: a method and its rationale. Illinois Natural History Survey Special Publication 5. 28 pp.

Ludwig, D.R., M. Redmer, R. Domazlicky, S.N. Kobal, and B. Conklin. 1992. Current status of amphibians and reptiles in Du Page County, Illinois. Transactions of the Illinois State Academy of Science 85(3-4):187-199.

Mauger, D. 1986. Rattlesnake finding report. Unpublished forest preserve district memorandum September 23, 1986, Joliet, Illinois. 4 pp.

Mauger, D. 1988. Conservation of the spotted turtle (Clemmys guttata Schneider) in Illinois: a preliminary plan. Graduate research project submitted jointly to P. Klingensmith, Governors State University, and the Forest Preserve District of Will County, Joliet. 20 pp.

Mauger, D. 1999. 1999 massasauga monitoring report. Unpublished report to the Forest Preserve District of Will County. 25 pp.

Mauger, D., and T. Anton. 2003. Current distribution and status of amphibians and reptiles in Kankakee County, Illinois. Bulletin of the Chicago Herpetological Society 38(5):89-95.
Mauger, D., and T. Anton. 2006. Herpetofaunal quality index (HQI): a method to assess conservation importance of amphibian and reptile assemblages. Unpublished poster presentation at PARC Midwest Annual Meeting, Sept. 7-9, Carbondale, Illinois.

Mauger, D., and J. DalPonte. 1998. A herpetofaunal survey of McKinley Woods \& Laughton Forest preserves. Unpublished report to the Forest Preserve District of Will County, Joliet, Illinois. $10 \mathrm{pp}$.

Mauger, D., and C. Robeson-Musial. 2000. A pilot study of guild composition and diversity of pondbreeding salamanders at two upland depressions in Thorn Creek Woods Nature Preserve. Unpublished report to Thorn Creek Woods Management Commission, Park Forest, Illinois, March, 2000. $26 \mathrm{pp}$.

Mauger, D., and T.P. Wilson. 1999. Population characteristics and seasonal activity of S. catenatus catenatus in Will County, Illinois: implications for management and monitoring. Pages 110-124 in Second International Symposium and Workshop on the Conservation of the Eastern Massasauga Rattlesnake, Sistrurus catenatus catenatus. B. Johnson and M. Wright, eds. Toronto Zoo, Toronto, Ontario.

Mauger, D., T. Bell, and E.L. Peters. 2000. Distribution and habitat of the southern two-lined salamander, Eurycea cirrigera, in Will County, Illinois: implications for population management and monitoring. Journal of the Iowa Academy of Sciences 107(3):168-174.

McDiarmid, R.W., M.S. Foster, C. Guyer, J.W. Gibbons, and N. Chernoff. 2012. Reptile biodiversity: standard methods for inventory and monitoring. University of California Press, Berkeley. 412 pp.

Mierzwa, K.S. 1988. Amphibians and reptiles in Will County, Illinois. Unpublished report to the Forest Preserve District of Will County.

Mierzwa, K.S. 1989. Distribution and habitat of the two-lined salamander, Eurycea cirrigera, in Illinois and Indiana. Bulletin of the Chicago Herpetological Society 24:61-49. 
Mierzwa, K.S. 1998. Status of northeastern Illinois amphibians. Chapter 16 in M.J. Lannoo, ed. Status and conservation of midwestern amphibians. University of Iowa Press, Iowa City.

Minton, S. A. 2001. Amphibians and reptiles of Indiana. Revised 2nd ed., Indiana Academy of Sciences, Indianapolis. 404 pp.

Morris, M.A., R.S. Funk, and P.W. Smith. 1983. An annotated bibliography of the Illinois herpetological literature 1960-1980, and an updated checklist of species of the state. Illinois Natural History Survey Bulletin 33:123-138.

Necker, W.L. 1938. Checklist of reptiles and amphibians of the Chicago region. Chicago Academy of Sciences Leaflet 1.

Necker, W.L. 1939. Records of amphibians and reptiles of the Chicago region, 1935-1938.

Chicago Academy of Sciences Bulletin 6:1-10.

O'Connell, Daniel J. 1992. A herpetofaunal survey of the Braidwood Dune and Savanna Nature Preserve. MS thesis, Eastern Illinois University, Charleston. 55 pp.

Pentecost, E.D., and R.C. Vogt. 1976. The amphibians and reptiles of the Lake Michigan drainage basin. Vol. 16, pages 1-76 in Environmental status of the Lake Michigan region. Argonne National Laboratory, Argonne, Illinois.

Phillips, C.A., R.A. Brandon, and E.O. Moll. 1999. Field guide to amphibians and reptiles of Illinois. Illinois Natural History Survey, Manual $8.300 \mathrm{pp}$.

Pope, C.H. 1947. Amphibians and reptiles of the Chicago area. Chicago Natural History Museum.

Redmer, M. 1998. Status and distribution of two uncommon frogs, pickerel frogs and wood frogs, in Illinois. Chapter 12 in M.J. Lannoo, ed. Status and conservation of midwestern amphibians. University of Iowa Press, Iowa City.

Redmer, M. 2012. Illinois Wildlife Preservation Fund state-wide survey for the ornate box turtle (Terrapene ornata). Final Report 11-L03W. Unpublished report to The Conservation Foundation. $18 \mathrm{pp}$.
Schmidt, K.P. 1938. Herpetological evidence for the post-glacial eastward expansion of the steppe in North America. Ecology 19:396-407.

Schmidt, K.P., and W.L. Necker. 1935. Amphibians and reptiles of the Chicago region. Chicago Academy of Sciences Bulletin 5(4):57-77.

Schwegman, J. 1973. Comprehensive plan for the Illinois Nature Preserve System, Part 2. The natural divisions of Illinois. Illinois Nature Preserves Commission, Springfield. 32 pp.

Smith, P.W. 1957. An analysis of post-Wisconsin biogeography of the Prairie Peninsula region based on distributional phenomena among terrestrial vertebrate populations. Ecology 38(2):205-218.

Smith, P.W. 1961. The amphibians and reptiles of Illinois. Illinois Natural History Survey Bulletin 28(1):1-298.

Smith, P.W., and S.A. Minton. 1957. A distributional summary of the herpetofauna of Indiana and Illinois. American Midland Naturalist 58(2) :341-351.

Stille, W.T., and R.A. Edgren. 1948. New records for amphibians and reptiles in the Chicago area, 1939-1947. Chicago Academy of Sciences Bulletin 8(7):195-202.

Strond, B. 1992. Final report: preliminary survey and description of the massasauga population in Goodenow Grove. Unpublished report to the Forest Preserve District of Will County. 14 pp.

Swink, F., and G. Wilhelm. 1994. Plants of the Chicago region. 4th ed. Indiana Academy of Science, Indianapolis.

Taft, J.B., G. Wilhelm, D. Ladd, and L. Masters. 1997. Floristic quality assessment for vegetation in Illinois: a proposed method for assessing vegetation integrity. Erigenia 15:3-95.

Thomas, E.S. 1951. Distribution of Ohio animals. Ohio Journal of Science 51:153-167. 
APPENDIX 1. Material examined. All are single specimens, or specimens in sequence. All specimens are preserved in alcohol. Refer to page 2 for institution acronyms.

Acris crepitans: CA 1574-75, 15322, 15463, 18684; FMNH 2091, 5568, 5570, 6271-75, 6299, 41087-88, 162276-16299; 16300-307, 247704, 251300, 257096; INHS 10914, 11914, 18398-99, 20287-99; 20300, 26741-43, 93713-17; NU 92-96; UIMNH 26741-43.

Anaxyrus americanus: CA 13413, 15211; FMNH 5971, 6276-77, 7456-59, 251296, 251302, 255999, 259650; INHS 10787-88, 10792, 10828, 11283, 11294, 11964, 12028, 12619, 12624-25, 14147-48, 14921-23, 14963-65, 15412-17, 15499, 15702, 17521, 18110, 18128, 18400, 18579, 19503. Anaxyrus fowleri: INHS 19127. Hyla versicolor: CA 15323; FMNH 162138-39, 255766, 260353; INHS 11298, 11301, 11305, 11307-08, 11965-66, 12622-23, 12626-28, 15094-15101, 15516, 17505-06, 17524, 17750, 17755, 17809-10, 18113, 18122, 18943-46, 20479. Pseudacris crucifer: INHS 11300, 11302-04, 11306, 11309, 11466, 11973-79, 12030-31, 12630-33, 15525. Pseudacris triseriata: FMNH 5969-70, 6269-70, 7447-49, 7467-68, 15996, 161862, 162837-38, 251301, 256991-92, 258967; INHS 10777, 11182, 11297, 11299, 12019, 12629, 12634-35, 1492425, 14932-61, 14966-79, 16430, 17519, 18112. Lithobates blairi: CA 7706, 15333, 15336, 15338; INHS 18108, 18535. Lithobates catesbeianus: FMNH 251309, 259651, 262223; INHS 10793, 11290, 11465, 11963, 12027, 12080, 12613, 12814, 13202, 13474-75, 14151, 14980, 15110, 17808, 18114-15, 18124, 18549; SIUC-H 6600. Lithobates clamitans: CA 15324-30, 1546467; FMNH 5567, 5569, 37704-07, 44419, 155785, 251310; INHS 10826, 11295, 12026, 12213 , 12614, 13203, 14180, 14926, 17509, 17527, 18401; NU 169; SIUC-H 6601. Lithobates pipiens: CA 5030, 15331-32, 15334-35, 15337, 15468; FMNH 7446, 7460-66, 35500, 161893, 162004, 236045, 250095, 251303-08, 255767, 257474, INHS 10789, 10799, 11293, 11296, 11915, 11918, 12011, 12016-17, 12025, 12105-06, 12620-21, 12815, 13462-63, 13476, 14149-50, 14927, 14962, 14992, 15103, 15111, 17508, 17510, 17522, 17531, 17807, 18111, 18123, 18541-42, 19128; UIMNH 26769-75. Lithobates sylvaticus: INHS 12023-24. Ambystoma laterale: FMNH 259070; INHS 10781, 10784, 11280-81, 11949-50, 11967-71, 12018, 12029, 12503-04, 12590-91, 13467, 17777, 18598-99, 18601-02; UMMZ 124010. Ambystoma maculatum: FMNH 17602, 259071; INHS 11279, 11799, 11800-03, 14145, 18600. Ambystoma texanum: FMNH 281630; INHS 12589, 17525. Ambystoma tigrinum: FMNH 15975, 251293-95; INHS 9349, 10782-83, 11282, 11972 , 12020-22, 12211, 12588, 13483, 14928-31, 15408, 17526, 18109. Eurycea cirrigera: CA 1573; FMNH 235380-81; INHS 11459-64, 12014, 12592-93. Hemidactylium scutatum: INHS 12064. Necturus maculosus: FMNH 60887; INHS 7603. Notophthalmus viridescens: INHS 14700, 15760, 17507. Apalone spinifera: FMNH 251297; INHS 12147; SIUC-R 2709. Chelydra serpentina: CA 15230; FMNH 262548; INHS 11291, 11480, 12099, 12174, 12612, 17523, 17802-04, 18531, 18547, 19125, 19884. Chrysemys picta: FMNH 30418, 33667-68, 251320-21, 252409, 252415, 255768-69, 263877, 266850, 267588-89, 267600, 270531-32; INHS 11310, 11959, 12013, 12584$86,13465,15105,15514,17512-15,17530,17801,17805-06,18125,18423,18433,18548$, 19501, 19873, 19878, 19895; SIUC-R 2478. Clemmys guttata: FMNH 269640-43, 269484-86, 270545-47, 274109-12; INHS 10960-64, 11183, 11962, 13464, 17494-500, 19123-24, 19502, 19883, 19892-94, 20114-15, 20480-81, 20662, 21205-07. Emydoidea blandingii: CA 15286; FMNH 28499, 269487; INHS 18544-46, 19137, 20196, 21196-97, 21199, 21200-04, 21483-85. Graptemys geographica: FMNH 33651, 33669-70, 251332; INHS 12149, 12587, 18402. Sternotherus odoratus: CA 15285; FMNH 251298; INHS 10821, 13473. Terrapene carolina: FMNH 252410; INHS 12228, 19492, 19631, 19944. Terrapene ornata: INHS 12636, 21489. Trachemys scripta: FMNH 251323, 268818. Aspidoscelis sexlineatus: FMNH 142648; INHS 10778, 15407, 15409-11, 15648. Ophisaurus attenuatus: FMNH 75340; INHS 10779-80, 15406. Clonophis kirtlandii: FMNH 55662, 65902, 257450, 270556; INHS 11286, 11861, 11982, 12072, 18543, 18566, 19637, 20478. Coluber constrictor: CA 6177; FMNH 33645, 251447-48, 255805, 
Appendix 1 continued from previous page

266849, 269951; INHS 8476, 12103, 12601, 15649, 18126, 18408. Heterodon platirhinos: FMNH 251319; INHS 12101, 15106, 18405, 18532; SIUC-R 2716. Lampropeltis triangulum: CA 5031; FMNH 2432, 252408, 261714; INHS 8477, 10798, 11289, 12070, 18558. Nerodia rhombifer: INHS 21384. Nerodia sipedon: CA 6153-56, 13420, 15299, 15488-89, 16223; FMNH 2818-19, 26825, 33659-60, 251315, 251318, 255806, 257475, 262026, 262521; INHS 8864, 10825, 11882, 12077, 12109, 12199, 12604, 13204, 15014, 17528, 17783, 17793, 17799, 18136, 18403, 18537, 18553, 19115, 19639, 19875; NU 1; SIUC-R 3405. Opheodrys vernalis: FMNH 265291; INHS 3182, 10795, 11980-81, 12104, 12605-08, 15953, 17713, 17775, 17788, 18129-31; SIUC-R 4298. Pantherophis spiloides: INHS 11186. Pantherophis vulpinus: CA 1595, 5033-34, 13433, 15226, 15287, 15476, 16535; FMNH 2460, 3367, 25223, 28107, 33644, 46038, 251311, 251317 , 257023, 257113, 257123, 263876, 268029; INHS 4069, 10796-97, 11481-85, 12012, 12065, 12071, 12076, 12078-79, 12081, 12110-13, 12124, 12148, 12154, 12206-07, 12567, 12596, 12816, 13466, 13468-71, 14152-53, 15104, 15107-08, 17501, 17529, 17786-87, 17794, 18407, 18426, 18533, 18536, 18538, 18559, 18561-62, 18576-78, 19101, 19103, 19879-80; SIUC-R 2472, 2688, 2706. Pituophis catenifer: CA 19284; FMNH 38240; INHS 12015, 12098, 12123, 12568, 12599 , 15650-51, 18150, 18404, 18575, 19876-77. Regina septemvittata: CA 4401, 6157-58, 13421-22, 15291; FMNH 2816, 2820, 16130, 251449; INHS 10827, 17520, 17791; MPM 13724; SIUC-R 2739, 3406; UMMZ 52116. Sistrurus catenatus: FMNH 42355, 55850-53, 64727, 65319, 25161618; INHS 8485, 11184-85, 12074-75, 15102. Storeria dekayi: CA 7296, 13426, 15288-90, 16534, 18423; FMNH 251299, 251313-14, 157131, 257445, 262221-22, 262516, 262543, 271596; INHS 8069, 10785-86, 10794, 10822-23, 11471-75, 11986-87, 12069, 12176-77, 12179, 12181, 12185, 12189, 12195-97, 12204-05, 12210, 12600, 12615-18, 12813, 13452, 13459-61, 13477, 13481, 17502, 17772, 17774, 17779-17800, 18116-19, 18132, 18135, 18138, 18567, 19104-05, 19107, 19887; UIMNH 24483. Storeria occipitomaculata: INHS 8482, 11284, 11476, 13482, 17785. Thamnophis proximus: INHS 12096. Thamnophis radix: CA 4310, 15477, 16537; FMNH 2817 , 2968, 7455, 33650, 155025, 251316, 257126, 263455, 262027; INHS 8480, 10791, 10965, 11285 , 11467, 11983-85, 12066, 12100, 12108, 12155, 12192-94, 12201, 12208-09, 12214, 12594, 12602, 12610-11, 13478, 13480, 15518, 17503, 17511, 17773, 17778, 17795, 18127, 18133-34, 18137, 18530, 18534, 18550, 18563, 18573, 19113, 19889-90, 21473. Thamnophis sirtalis: CA 5032, 6159, 13423-25, 14596, 15228, 15308, 15339-40, 15478, 16536; FMNH 16072, 155153, 251312, 257125, 257446, 255771, 262549, 267338, 269952, 271595; INHS 8481, 10790, 10824, 11287-88, 11477-79, 11960-61, 12067-68, 12073, 12097, 12102, 12107, 12153, 12156, 12175, 12178, 12180, 12182-84, 12186-88, 21290-91, 12198, 12200, 12203, 12212, 12595, 12597-98, 12603, 12609 , 13452, 13472, 13479, 15109, 15150, 15727, 17504, 17789, 17792, 17796, 18120-21, 18406, $18551,18568,18574,19102,19114,19119,19122,19490,19874,19891$. 
APPENDIX 2. Unvouchered records examined. Numbers correspond to digital files or scanned slides in the Illinois Natural History Survey Database.

Ambystoma laterale: INHS unvouch 27208-09. Ambystoma maculatum: INHS unvouch 28080. Anaxyrus americanus: INHS unvouch 26542, 26681. Hemidactylium scutatum: INHS unvouch 26687. Necturus maculosus: INHS unvouch 28102. Notophthalmus viridescens: INHS unvouch 26991. Lithobates blairi: INHS unvouch 27155. Lithobates clamitans: INHS unvouch 26561. Lithobates pipiens: INHS unvouch 26562. Apalone spinifera: INHS unvouch 42353. Clemmys guttata: INHS unvouch 25872, 42289. Emydoidea blandingii: INHS unvouch 26069-70, 26080, 26107-08, 26432, 28083-84, 28108, 42340. Graptemys geographica: INHS unvouch 28007.

Terrapene ornata: INHS unvouch 42412, 42887-89. Clonophis kirtlandii: INHS unvouch 25956, 26955, 27205, 28016-27, 28061, 28099, 28100, 42468-72, 42477, 42477, 42590. Nerodia sipedon: INHS unvouch 42351. Opheodrys vernalis: INHS unvouch 26563, 28107. Pantherophis vulpinus: INHS unvouch 42350. Storeria dekayi: INHS unvouch 26541, 26560, 26680, 27206. Thamnophis proximus: INHS unvouch 42352, 27111. Thamnophis radix: INHS unvouch 26679. Thamnophis sirtalis: INHS unvouch 26543, 27207. Sistrurus catenatus: INHS unvouch 26716, 27248. 
NOTES 

RESEARCH INSTITUTE

Illinois Natural History Survey

Forbes Natural History Building

1816 South Oak Street

Champaign, Illinois 61820

217-333-6880 